\title{
Pharmacological targeting of phosphoinositide lipid kinases and phosphatases in the immune system: success, disappointment, and new opportunities
}

\section{Matthew D. Blunt and Stephen G. Ward*}

Inflammatory Cell Biology Laboratory, Department of Pharmacy and Pharmacology, University of Bath, Bath, UK

\section{Edited by:}

Klaus Okkenhaug, Babraham

Institute, UK

\section{Reviewed by:}

Matthias P. Wymann, University of Basel, Switzerland

William Garrow Kerr, SUNY Upstate Medical University, USA

\section{*Correspondence:}

Stephen G. Ward, Inflammatory Cell Biology Laboratory, Department of Pharmacy and Pharmacology,

University of Bath, Claverton Down, Bath BA2 7AY, UK.

e-mail:s.g.ward@bath.ac.uk
The predominant expression of the $\gamma$ and $\delta$ isoforms of PI3K in cells of hematopoietic lineage prompted speculation that inhibitors of these isoforms could offer opportunities for selective targeting of $\mathrm{PI} 3 \mathrm{~K}$ in the immune system in a range of immune-related pathologies. While there has been some success in developing PI3K $\delta$ inhibitors, progress in developing selective inhibitors of $\mathrm{PI} 3 \mathrm{~K} \gamma$ has been rather disappointing. This has prompted the search for alternative targets with which to modulate PI3K signaling specifically in the immune system. One such target is the $\mathrm{SH} 2$ domain-containing inositol-5-phosphatase1 (SHIP-1) which de-phosphorylates $\mathrm{PI}(3,4,5) \mathrm{P}_{3}$ at the $\mathrm{D} 5$ position of the inositol ring to create $\mathrm{PI}(3,4) \mathrm{P}_{2}$. In this article, we first describe the current state of PI3K isoformselective inhibitor development. We then focus on the structure of SHIP-1 and its function in the immune system. Finally, we consider the current state of development of small molecule compounds that potently and selectively modulate SHIP activity and which offer novel opportunities to manipulate PI3K mediated signaling in the immune system.

Keywords: activators, inflammation, inhibitors, leukemia, lymphocytes, PI3K, SHIP-1, SHIP-2

\section{INTRODUCTION}

Studies using mice in which the genes encoding PI3K $\delta$ or $\mathrm{PI} 3 \mathrm{~K} \gamma$ have been either altered to encode kinase-inactive mutants (e.g., $\mathrm{PI} 3 \mathrm{~K} \delta \delta^{\mathrm{D} 910 \mathrm{~A}}$ mice) or deleted, have revealed that $\mathrm{PI} 3 \mathrm{~K} \delta$ and $\mathrm{PI} 3 \mathrm{~K} \gamma$ have non-redundant (but often co-ordinated), functions in B cells, T cells, NK cell, neutrophils, mast cells, and dendritic cells (Vanhaesebroeck et al., 2005; Crabbe et al., 2007; Randis et al., 2008; Saudemont et al., 2009; Ward and MarelliBerg, 2009). Indeed, when the immune system of these mice is challenged they exhibit severely defective responses to infection (Vanhaesebroeck et al., 2005; Crabbe et al., 2007; Ward and Marelli-Berg, 2009). The predominant expression of the $\gamma$ and $\delta$ isoforms of PI3K in cells of hematopoietic lineage prompted speculation that inhibitors of these isoforms could offer selective targeting of PI3K in the immune system in a range of inflammatory and autoimmune diseases as well as in transplantation and hematological malignancies. While there has been some success in developing PI3K $\delta$ inhibitors, progress in developing selective inhibitors of PI3K $\gamma$ has been rather disappointing. This has prompted the search for alternative targets with which to modulate PI $3 \mathrm{~K}$ signaling specifically in the immune system. In this regard, attention has recently focused on the lipid phosphatase $\mathrm{SH} 2$ domain-containing inositol-5phosphatase (SHIP), which de-phosphorylates $\mathrm{PI}(3,4,5) \mathrm{P}_{3}$ at the $\mathrm{D} 5$ position of the inositol ring to create $\mathrm{PI}(3,4) \mathrm{P}_{2}$. This review will focus predominantly on the role of SHIP as a potential therapeutic target in the immune system and consider progress in developing small molecule drugs that target this protein.

\section{DEVELOPMENT OF INHIBITORS TARGETING PI3K $\gamma$ AND PI3K - THE STORY SO FAR}

There have been huge advances in the design of PI3K inhibitors which utilize the ATP-binding pocket of PI3K to achieve greater potency and selectivity as well as reduced toxicity (Walker et al., 2000; Knight et al., 2006; Berndt et al., 2010). The development of PI3K inhibitors with which to treat cancers has made substantial recent progress (for in depth reviews on this subject see Marone et al., 2008; Workman et al., 2010; Fruman and Rommel, 2011; Shuttleworth et al., 2011; So and Fruman, 2012). However, the development of PI3K inhibitors to treat inflammatory disorders has to date, been less successful.

The discovery of the quinazolinone purine series, exemplified by the ICOS compound IC-87114 (Figure 1) demonstrated that the design of isoform-selective PI3K inhibitors with at least 50 -fold potency over other isoforms was possible to achieve (Sadhu et al., 2003). In 2006 several members of ICOS Corporation formed a spin-out company, Calistoga Pharmaceuticals. Calistoga developed CAL-101, a PI3K $\delta$ specific inhibitor that exhibits 40-300-fold selectivity over other PI3K isoforms. CAL-101 which was acquired by Gilead in February 2011 and recently renamed GS-1101, has shown success in clinical trials for treatment of B cell malignancies where it causes rapid lymph node shrinkage and lymphocytosis (Fruman and Rommel, 2011; Hoellenriegel et al., 2011; Lannutti et al., 2011; So and Fruman, 2012). CAL-101 displays a dual mechanism of action whereby it both decreases cell survival and reduces chemokine-mediated interactions that retain CLL cells in protective tissue microenvironments (Hoellenriegel et al., 2011; Lannutti et al., 2011). These effects have been observed across a broad 


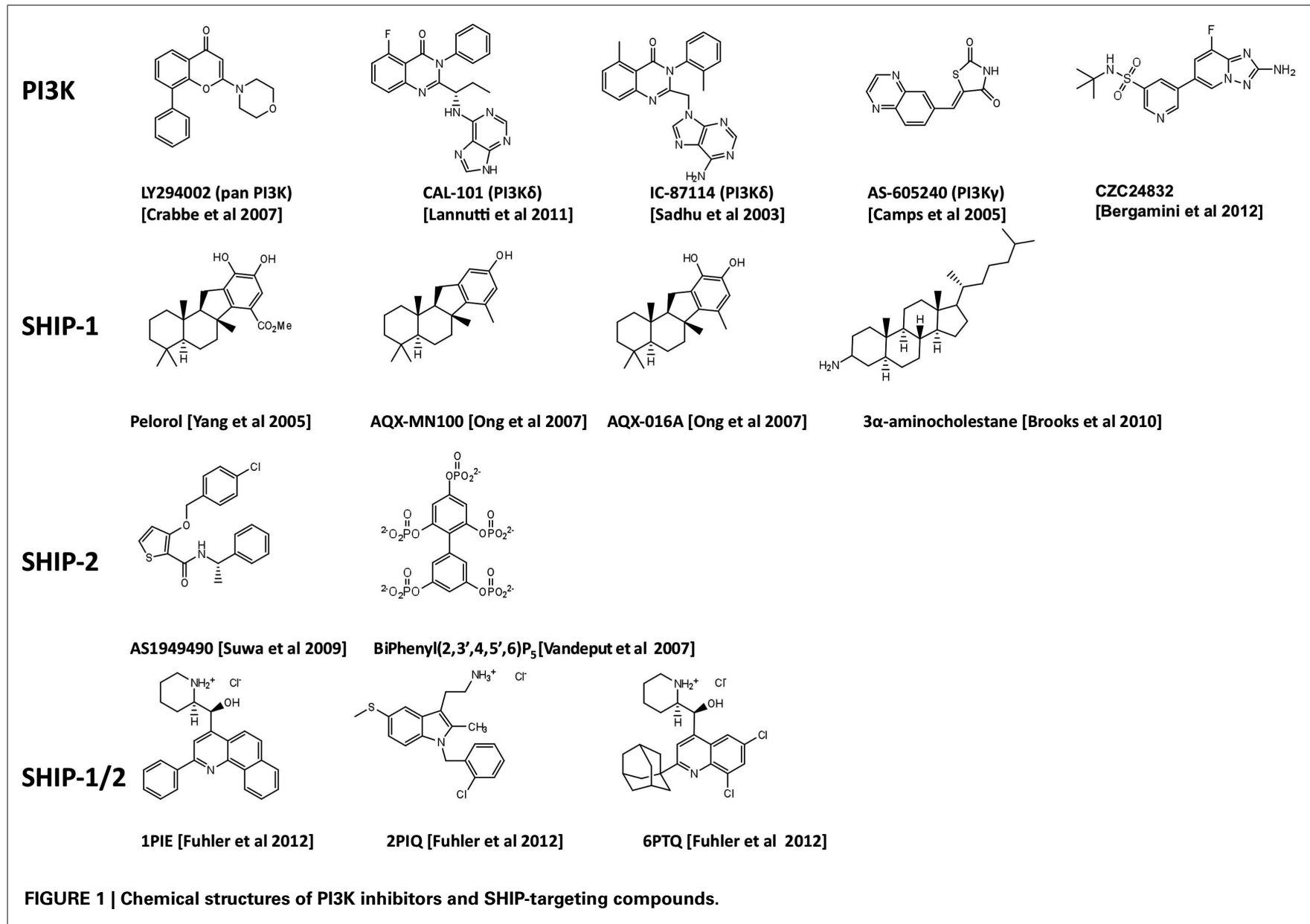

range of other immature and mature $B$ cell malignancies including $\mathrm{CD}^{+}$mantle zone B cell lymphomas, follicular lymphomas, and multiple myeloma (Herman et al., 2010; Ikeda et al., 2010; Fruman and Rommel, 2011; Hoellenriegel et al., 2011; Lannutti et al., 2011). Hodgkin lymphoma (HL) is a malignant lymphoma of Bcell origin. The malignant cells, known as Reed-Sternberg (RS) cells, represent less than $2 \%$ of the tumor mass, the remainder composed of a mix of reactive inflammatory cells attracted by the RS cells. Recently Hodgkin Lymphoma (HL) cell lines and primary samples from patients with HL have been reported to express high level of PI3K $\delta$ and constitutive PI3K pathway activation (Meadows et al., 2012). As with CLL, CAL-101 was able to reduce the positive interaction between stromal cells and malignant RS cells. This inhibitor has therefore, demonstrated an essential role for $\mathrm{PI} 3 \mathrm{~K} \delta$ in constitutive PI3K signaling that is required for the survival of malignant B cells. Oncogenic mutations of components of the PI3K signaling pathway are infrequent in B cell malignancies. A potential mechanism for PI3K activation in this setting is tonic antigen-independent $\mathrm{B}$ cell receptor (BCR) signaling that requires $\mathrm{PI} 3 \mathrm{~K} \delta$ for the transduction of proliferation and survival signals.

Inhibition of the PI3K $\delta$ isoform for the treatment of inflammatory disorders is also being explored. Specifically, CAL-101 and CAL-263 have entered clinical trials for allergic rhinitis (Table 1). In addition, patents have been filed by several other companies
(Amgen, Intellikine, and Incyte) describing PI3K $\delta$ inhibitors and the majority are based on the same basic pharmacophore identified by ICOS (Norman, 2011). However, additional scaffolds have now been reported by several companies; almost all of these are with intended indications against B cell lymphomas (Norman, 2011).

Whilst there has been considerable success in designing $\mathrm{PI} 3 \mathrm{~K} \delta$-selective inhibitors with promise against lymphoid malignancies, the progress in designing PI3K inhibitors for antiinflammatory/autoimmune applications has been disappointing. Compounds that selectively inhibit PI3K $\gamma$ have been identified, with a series of compounds designed by Merck Serono SA based on the thiazolidinedione scaffold (Ruckle et al., 2006). One of these, AS-605240 (Figure 1), exhibited superior potency compared to related compounds, can be administered orally and has high cell membrane permeability (Barber et al., 2005). These class of compounds have been proven useful as experimental tools but do not have requisite drug-like properties and have limited selectivity over other class 1A PI3K isoforms. Possible reasons for the relatively slow progress in developing $\mathrm{PI} 3 \mathrm{~K} \gamma$ inhibitors include the close structural conservation of class I PI3Ks and other lipid kinases in the ATP-binding pocket and the limited ability of the commonly used in vitro assays based on recombinant enzymes, to predict cellular and in vivo kinase selectivity. However, Cellzome recently 
Table 1 | Clinical trials status of PI3K and SHIP-1 targeting compounds for the treatment of inflammatory disorders.

\begin{tabular}{|c|c|c|c|c|c|c|}
\hline Compound & $\begin{array}{l}\text { Inflammatory } \\
\text { disorder }\end{array}$ & $\begin{array}{l}\text { Protein } \\
\text { target }\end{array}$ & $\begin{array}{l}\text { Clinical } \\
\text { trial } \\
\text { phase }\end{array}$ & $\begin{array}{l}\text { Status of } \\
\text { clinical trial }\end{array}$ & Company & Reference \\
\hline$A Q X-1125$ & Asthma & SHIP-1 & Ila & Initiated & $\begin{array}{l}\text { Aquinox Phar- } \\
\text { maceuticals }\end{array}$ & $\begin{array}{l}\text { http://www.aqxpharma.com/content/aquinox-pharmaceuticals- } \\
\text { initiates-two-phase-iia-clinical-studies-airway-inflammation }\end{array}$ \\
\hline CAL-101 & $\begin{array}{l}\text { Allergic } \\
\text { rhinitis }\end{array}$ & $\mathrm{PI} 3 \mathrm{~K} \delta$ & 1 & Completed & Gilead Sciences & http://clinicaltrials.gov/ct2/show/NCT00836914 \\
\hline CAL-263 & $\begin{array}{l}\text { Allergic } \\
\text { rhinitis }\end{array}$ & $\mathrm{PI} 3 \mathrm{~K} \delta$ & 1 & Completed & Gilead Sciences & http://clinicaltrials.gov/ct2/show/NCT01066611 \\
\hline $\mid \mathrm{Pl}-145$ & $\begin{array}{l}\text { Inflammatory } \\
\text { disorders }\end{array}$ & $\mathrm{PI} 3 \mathrm{~K} \delta / \gamma$ & 1 & Initiated & $\begin{array}{l}\text { Infinity and } \\
\text { Intellikine }\end{array}$ & http://www.intellikine.com/pipeline/ipi145.html \\
\hline
\end{tabular}

described a chemoproteomics-based drug discovery platform that enables multiplexed high-throughput screening of native proteins in cell extracts. The chemoproteomic approach preserves posttranslational modifications and protein interactions and hence allows targeting of $\mathrm{PI} 3 \mathrm{~K}$ proteins under close-to-physiological conditions in human primary cells (Bergamini et al., 2012). Using affinity enrichment of target kinases afforded by immobilized ATP-competitive lipid kinase inhibitors, the potency of small molecule test compounds was evaluated in competition binding assays. This revealed CZC24832 which exhibits superior selectivity for PI3K $\gamma$ than previously reported compounds (Camps et al., 2005; Bergamini et al., 2012). Interestingly, CZC24832 shows antiinflammatory effects in a collagen-induced arthritis model that correlated with reduced Th17 differentiation, a pro-inflammatory helper T cell type characterized by expression of the cytokine IL17 (Weaver and Murphy, 2007). Indeed, CZC24832 treatment also led to reduced IL-17 production (Bergamini et al., 2012). This confirms the long-held belief that pharmacological inactivation of PI3K $\gamma$ alone, can lead to amelioration of inflammatory disease. This recent breakthrough, may facilitate detailed mechanistic studies of PI3K $\gamma$ in human primary cells and allow human clinical studies in inflammation.

The non-redundant and often co-ordinated roles of PI3K $\delta$ and PI3K $\gamma$ in immune cell function have been reported (Rommel et al., 2007) and provide a rationale for targeting both isoforms simultaneously with a single compound. Indeed, TargeGen described two diaminopteridine-diphenol-based compounds with good selectivity for PI3K $\gamma$ and $\mathrm{PI} 3 \mathrm{~K} \delta$ that showed early promise in animal models of myocardial ischemia as well as asthma and chronic obstructive pulmonary disease (Doukas et al., 2006, 2009). The TargeGen compounds did not progress beyond phase I/II clinical trails. However, Infinity and Intellikine are currently in pre-clinical trials with IPI-145 (Table 1), which is the only PI3K $\gamma / \delta$ inhibitor currently in development for the treatment of inflammatory disease (Norman, 2011).

There is an increasing appreciation of a role for PI3K $\beta$ in the immune system including cooperation with PI3K $\delta$ in the generation of reactive oxygen species (ROS) in neutrophils in response to fungal infection or immune complexes (Boyle et al., 2011; Kulkarni et al., 2011). Signaling responses of several Gi-coupled receptors including those for the leukocyte chemoattractants C5a and fMLP has been demonstrated to occur at least in part via PI3K $\beta$
(Guillermet-Guibert et al., 2008). Indeed, loss of PI3K $\beta$ confers substantial protection in a mouse model of a human autoimmune blistering disease (Boyle et al., 2011; Kulkarni et al., 2011). Loss of PI3K $\beta$ also partially (but significantly), protected against the development of clinical signs of arthritis in response to low does of arthritogenic serum in the $\mathrm{K} / \mathrm{BxN}$ mouse model of rheumatoid arthritis. However, no protection was seen mice lacking either $\mathrm{PI} 3 \mathrm{~K} \beta$ or expressing kinase-dead PI3K $\delta$ subjected to higher does of arthritogenic serum. Remarkably, mice lacking both PI3K $\beta$ and $\mathrm{PI} 3 \mathrm{~K} \delta$ activity were highly protected at both high and low doses of $\mathrm{K} / \mathrm{BxN}$ serum. Collectively, these data provide a rationale for targeting $\mathrm{PI} 3 \mathrm{~K} \beta$ as well as $\mathrm{PI} 3 \mathrm{~K} \delta$ in the treatment of inflammatory disorders. Such dual isoform inhibitors could offer some benefit in certain therapeutic settings, though it is important to recognize that the pathogenesis of human inflammatory diseases such as RA is complex and multi-factorial. As such, the precise contribution of each isoform to disease pathology is likely to be subtle and complex. Nevertheless, compounds with dual selectivity for PI3K $\beta$ and $\mathrm{PI} 3 \mathrm{~K} \delta$ have been reported suggesting that this approach is feasible (Knight et al., 2006). However, caution should be applied to the use of PI3K $\beta$ inhibitors in inflammatory disorders due to the described role of PI3K $\beta$ in thrombus formation and circulatory homeostasis (Bird et al., 2011).

\section{INCREASED UNDERSTANDING OF A ROLE FOR OTHER PI3KS IN THE IMMUNE SYSTEM}

The difficulties of developing PI3K $\gamma$ inhibitors with sufficient selectivity over PI3K isoforms has led to the search for other targets that might offer opportunities to selectively disrupt PI3K signaling in immune cells. To this end, class II PI3KC2 $\beta$, has been demonstrated to play an important and unexpected role in CD4 ${ }^{+} \mathrm{T}$-cell activation downstream of the TCR (Srivastava et al., 2009), while Vps34's role in autophagy (Backer, 2008; Simonsen and Tooze, 2009), suggests it may prove important for immune recognition of tumor antigens, regulation of $\mathrm{T}$ cell homeostasis, and immune tolerance (Li et al., 2008; Nedjic et al., 2008; Walsh and Edinger, 2010). There is considerable evidence that class III PI3K is important for phagocytosis (Fratti et al., 2001; Vieira et al., 2001; Ellson et al., 2006; Anderson et al., 2008). There may be opportunities to target Vps34 in destructive inflammatory/autoimmune diseases where there is dysregulated phagosomal activity and antigen presentation of self molecules, for example. The publication of the 
Vps34 crystal structure in complex with PI3K inhibitors may allow the design of more potent and selective Vps34 inhibitors which are able to exploit differences between Vps34 and Class 1 PI3Ks (Miller et al., 2010). However, the largely ubiquitous expression of Class II and III PI3Ks makes selective targeting of the immune system problematic.

\section{SHIP-1: AN ALTERNATIVE TARGET FOR MODULATION OF PI3K SIGNALING IN THE IMMUNE SYSTEM}

The search for alternative targets with which to modulate PI3K signaling specifically has therefore, recently focused on the lipid phosphatase $\mathrm{SH} 2$ domain-containing inositol-5-phosphatase-1 (SHIP1 ), which de-phosphorylates $\mathrm{PI}(3,4,5) \mathrm{P}_{3}$ at the $\mathrm{D} 5$ position of the inositol ring to create $\mathrm{PI}(3,4) \mathrm{P}_{2}$. The INPP5D gene located on chromosome 2 (2q37.1) encodes the $145-\mathrm{kDa}$ SHIP-1 which was originally recognized as an important component of the inhibitory signaling pathway triggered by the IgG receptor Fc $\gamma$ RIIB in mast cells and B cells (Ono et al., 1996). Once recruited to the plasma membrane by signaling complexes, its catalytic activity depletes $\mathrm{PI}(3,4,5) \mathrm{P}_{3}$ and prevents membrane localization of some $\mathrm{PH}$ domain-containing effectors, leading to inhibition of extracellular calcium influx and ultimately reducing transcription activation, and cytokine release. One would predict that activators of SHIP-1 would lead to a reduction of cellular $\mathrm{PI}(3,4,5) \mathrm{P}_{3}$ levels and hence, mimic the effect of PI3K inhibitors. Its hematopoietic-restricted expression should limit the impact of SHIP-1 targeted drugs to the immune system making SHIP-1 an attractive drug target for use in inflammatory and autoimmune diseases, hematological malignancies as well as in transplantation settings.

\section{SHIP-1: A CROSSROADS IN PI3K-DEPENDENT SIGNALING}

The classical view of SHIP-1 is that it acts to switch off PI3Kdependent signaling by degradation of $\mathrm{PI}(3,4,5) \mathrm{P}_{3}$. However, the metabolism of $\mathrm{PI}(3,4,5) \mathrm{P}_{3}$ by SHIP-1 yields $\mathrm{PI}(3,4) \mathrm{P}_{2}$ which retains the phosphate grouping on the third position of the inositol ring and thus, may retain some signaling ability (Figure 2). Pleckstrin homology $(\mathrm{PH})$ domains encoded in many proteins (e.g., Grp-1, Gabs, and Btk) bind exclusively to $\mathrm{PI}(3,4,5) \mathrm{P}_{3}$, whereas others such as those found in dual adaptor of phosphotyrosine and 3-phosphoinositides-1 (DAPP1) and Src kinase-associated phosphoprotein (SKAP), can interact with both $\mathrm{PI}(3,4,5) \mathrm{P}_{3}$ and $\mathrm{PI}(3,4) \mathrm{P}_{2}$ (Lemmon and Ferguson, 2000; Zhang et al., 2009). In addition, the tandem $\mathrm{PH}$ domain-containing protein TAPP1 encodes $\mathrm{PH}$ domains that show selectivity toward $\mathrm{PI}(3,4) \mathrm{P}_{2}$ (Dowler et al., 2000). The ability of $\mathrm{PH}$ domain-containing proteins to distinguish between different 3 '-phosphoinositide lipids suggests that SHIP-1 can act as a switch to redirect PI3K-dependent signaling toward a set of distinct effectors that are temporally and functionally separate from $\mathrm{PI}(3,4,5) \mathrm{P}_{3}$-dependent events. Thus, SHIP-1 may function to fine-tune phosphoinositide signaling, rather than terminate it. In this regard, SHIP-1 promotes recruitment of the GTPase Irgm 1 to sites of phagocytosis in macrophages

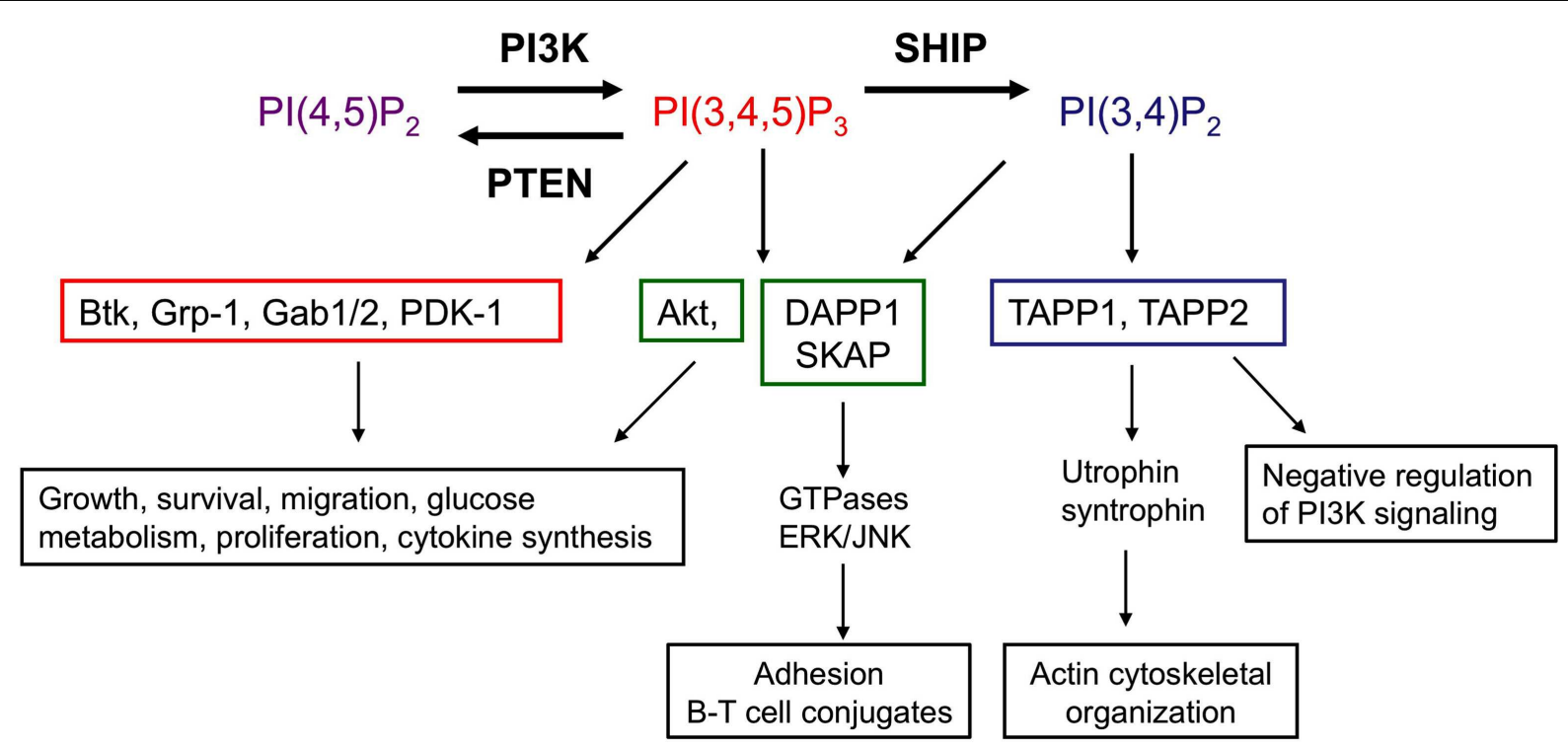

FIGURE 2 | SHIP acts as a molecular "switch." SHIP catalyzes the conversion of the $\mathrm{PI} 3 \mathrm{~K}$ lipid product $\mathrm{PI}(3,4,5) \mathrm{P}_{3}$ to $\mathrm{PI}(3,4) \mathrm{P}_{2}$. Effector proteins which express $\mathrm{PH}$ domains are recruited and activated by these lipid second messengers at the cell surface membrane. $\mathrm{PH}$ domains of proteins are able to discriminate between $\mathrm{PI}(3,4,5) \mathrm{P}_{3}$ and $\mathrm{PI}(3,4) \mathrm{P}_{2}$. Examples of proteins which bind only $\mathrm{PI}(3,4,5) \mathrm{P}_{3}$ (red), both $\mathrm{PI}(3,4,5) \mathrm{P}_{3}$ and $\mathrm{PI}(3,4) \mathrm{P}_{2}$ (green), or only $\mathrm{PI}(3,4) \mathrm{P}_{2}$ (blue) as well as functional consequences are shown, though there are many other $\mathrm{PH}$ domain proteins present in immune cells and this is not an exhaustive list. Functional read-outs downstream of $\mathrm{PI}(3,4,5) \mathrm{P}_{3}$-interacting proteins and Akt are context dependent, have been extensively reviewed elsewhere
(Manning and Cantley, 2007; Vanhaesebroeck et al., 2010, 2012) and are summarized in this figure. Lesser known interacting partners of $\mathrm{PI}(3,4) \mathrm{P} 2$-dependent TAPP-1/2 and PI $(3,4) \mathrm{P} 2 / \mathrm{PI}(3,4,5) \mathrm{P}_{3}$-dependent DAPP1 with roles in immune function are indicated (Costantini et al., 2009; Zhang et al., 2009; Vanhaesebroeck et al., 2010; Wullschleger et al., 2011; So and Fruman, 2012). Abbreviations: Btk, Bruton's tyrosine kinase; Gab1, GRB2-associated binding protein-1; Grp-1, general receptor for phosphoinositides 1; PDK-1, phosphoinositide lipid-dependent kinase-1; DAPP1, dual-adapter for phosphotyrosine and 3-phosphoinositides 1; SKAP, src kinase-associated phosphoprotein; TAPP, tandem pleckstrin homology domain protein. 
via generation of $\mathrm{PI}(3,4) \mathrm{P}_{2}$, a critical step in maturation of the phagosome and engulfment of bacteria (Tiwari et al., 2009). $\mathrm{PI}(3,4,5) \mathrm{P}_{3}$ and $\mathrm{PI}(3,4) \mathrm{P}_{2}$ appear sequentially following agonist stimulation in many cell types including $\mathrm{T}$ lymphocytes, but show temporal overlap. Some cell types, notably B lymphocytes and platelets, exhibit sustained $\mathrm{PI}(3,4) \mathrm{P}_{2}$ production, lasting for up to 45-60 min post-stimulation (Sorisky et al., 1992; Brauweiler et al., 2001).

\section{NON-ENZYMATIC ACTIVITIES OF SHIP-1}

SH2 domain-containing inositol-5-phosphatase-1 protein possesses numerous structural domains in addition to its single catalytic domain (Figure 3). The catalytic domain is responsible for the hydrolysis of the 5-phosphate group on the PI3K product $\mathrm{PI}(3,4,5) \mathrm{P}_{3}$ to form $\mathrm{PI}(3,4) \mathrm{P}_{2}$. Under basal conditions, SHIP-1 is located in the cell cytosol and upon receptor ligation is recruited to the surface membrane, bringing SHIP-1 within close proximity to its lipid substrate. Numerous structural domains are required for
SHIP-1 to successfully re-localize to the surface membrane. The $\mathrm{SH} 2$ domain within SHIP-1 interacts with proteins via the consensus amino acid sequence $\mathrm{pY}[\mathrm{Y} / \mathrm{S}][\mathrm{L} / \mathrm{Y} / \mathrm{M}][\mathrm{L} / \mathrm{M} / \mathrm{I} / \mathrm{V}]$. Through this SH2 domain, SHIP-1 binds to tyrosine phosphorylated proteins such as Shc, Doks, Gabs, CD150, platelet-endothelial cell adhesion molecule (PECAM), Cas, c-Cbl, certain immunoreceptor tyrosine-based inhibitory motifs (ITIMs), and some immunoreceptor tyrosine-based activation motifs (ITAMs). Proline rich regions within the C-terminal enable SHIP-1 to bind proteins that contain a $\mathrm{SH} 3$ domain, for example phospholipase- $\mathrm{C} \gamma$ and Grb-2. The phosphorylation of tyrosine residues within the NPXY motifs at the C-terminal tail of SHIP-1 provides sites of interaction for various proteins which express phosphotyrosine-binding (PTB) domains, such as Shc, Dok1, and Dok2. A newly identified structural domain has been recently identified whereby a segment of SHIP-1 adopts an independently folded structure predicted to have $\mathrm{PH}$ domain-like topology. This $\mathrm{PH}$-related ( $\mathrm{PH}-\mathrm{R})$ domain binds $\mathrm{PI}(3,4,5) \mathrm{P}_{3}$ and is required for localization of SHIP-1 to the

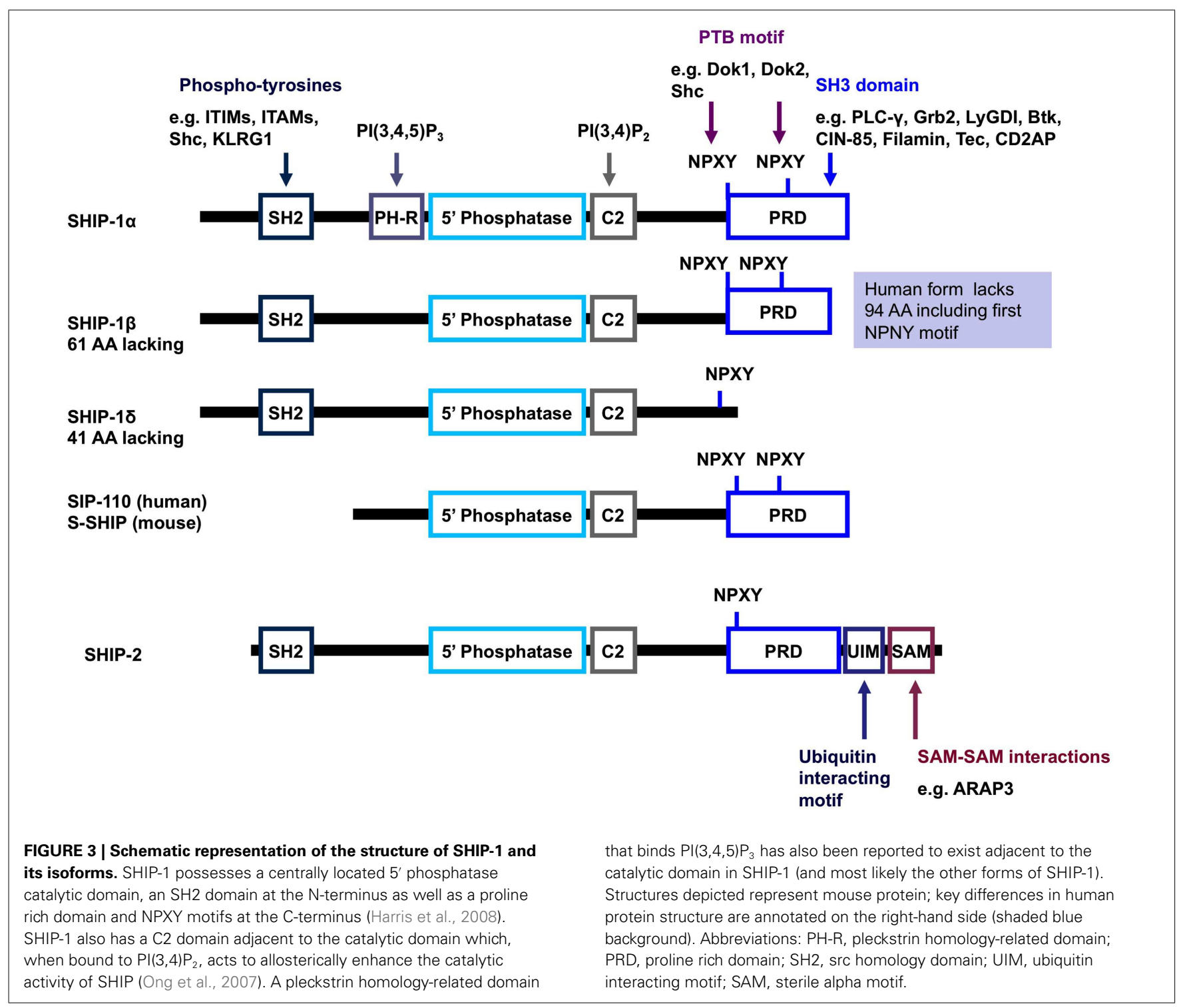


phagocytic cup and SHIP-1 mediated inhibition of Fc $\gamma$ R-mediated phagocytosis by macrophages (Ming-Lum et al., 2012).

The various structural domains not only serve to bring SHIP-1 in close proximity to its substrate at the surface membrane, but also allow SHIP-1 to perform a scaffolding role, recruiting other proteins to the surface membrane independent of its catalytic activity. Most of these interactions contribute to the negative regulation of PI3K signaling by SHIP independently of its catalytic activity. For example, binding of SHIP-1 to ITAM containing adaptor proteins via the $\mathrm{SH} 2$ domain, can prevent $\mathrm{PI} 3 \mathrm{~K}$ recruitment via the p85 regulatory subunit (Peng et al., 2010). Moreover, SHIP-1 has also been shown to block, independently of its catalytic activity, the recruitment of the tyrosine phosphatase SHP1 to the SLAM family receptor 2B4 in NK cells (Wahle et al., 2007). Indeed, there is a profound increase in SHP1 recruitment in SHIP null cells that tips the balance toward constitutive inhibitory signaling via 2B4 (Wahle et al., 2007). Other protein interactions allow SHIP-1 to negatively influence different signaling pathways. For example, in B lymphocytes following BCR and Fc $\gamma$ RIIB co-ligation, SHIP-1 interactions with Shc inhibit Ras/MAPK activation either by displacing Grb-2 and Sos from their interaction with Shc and/or by recruiting Dok1 and RasGAP to Fc $\gamma$ RIIB at the plasma membrane. In T cells, SHIP1 interacts with the Tec kinase and inhibits its function in $\mathrm{T}$ cells (Tomlinson et al., 2004a) and participates in a negative signaling complex comprising Grb-2-SHIP-1 and Dok1/2 that is recruited to LAT and inhibits Akt and PLC $\gamma$ activation (Dong et al., 2006).

There is evidence that the scaffolding role of SHIP-1 is not restricted to facilitating negative regulatory mechanisms. For example, adaptor functions of SHIP-1 potentiate EGF-induced PLC-gammal activation in COS cells over-expressing SHIP-1 (Song et al., 2005). In addition, SHIP-1 facilitates a positive regulatory role in TLR-induced cytokine production from mucosal mast cells (Ruschmann et al., 2012). Recently, SHIP-1 has been reported to interact via its proline rich region with the Cbl-interacting 85-kDa protein CIN85 (Buchse et al., 2011) and the related CD2associated adaptor protein (CD2AP) in Bao et al. (2012). In T cells, CIN85 binds to the adaptor molecule SH3 domain-binding protein-2 (3BP2), which is involved in leukocyte signaling downstream of Src/Syk-kinase coupled immunoreceptors and formation of the immunological synapse (Le Bras et al., 2007), though its role in B cells is unclear. In plasmacytoid dendritic cells, the CDAPSHIP-1 complex positively regulates BDCA2/FceR $1 \gamma$ signaling by inhibiting Cbl-mediated ubiquitination and degradation of the activated Syk and FceR1 $\gamma$ in plasmacytoid dendritic cells (Bao et al., 2012). Finally, it appears that the SH2 domain of SHIP-1 interacts (both intra- and inter-molecularly) with phosphorylated NPXY ${ }^{1020}$ within the SHIP-1 C-terminus that leads to dimerization and oligomerization (Mukherjee et al., 2012). SHIP-1 lacking its C-terminus is activated 8-10-fold more than full length SHIP-1 (Zhang et al., 2010), suggesting that the C-terminus not only controls interactions of SHIP-1 with respective binding partners, but also catalytic activity of SHIP-1.

\section{ROLE OF SHIP-1 IN REGULATING IMMUNE FUNCTION}

$\mathrm{SH} 2$ domain-containing inositol-5-phosphatase-1 is recruited to the surface membrane following ligation of a variety of receptors including, chemokine, Toll-like receptors (TLR), antigen, co-stimulatory, and cytokine receptors as well as IgG engagement by Fc $\gamma$ RIIB (Harris et al., 2008; Keck et al., 2010; Table 2). SHIP-1 knock-out mice have proven invaluable in identifying the crucial role of SHIP-1 in the regulation of mast cell degranulation, BCR signaling and auto-antibody production, dendritic cell function, and NK cell cytolytic function (Table 3). SHIP-1 also regulates TLR signaling (Sly et al., 2004; Gabhann et al., 2010; Ruschmann et al., 2012), leukocyte polarization, and migration (Nishio et al., 2007; Harris et al., 2011; Mondal et al., 2012). It has also been shown to play a central role in CD4-mediated inhibitory signaling activated by HIV-1 gp120 that leads to disarmament of the immune systems (Waterman et al., 2012). Remarkably, there is evidence that SHIP is able to influence PI3K signaling not only at receptors it is recruited to (in cis) but also at other receptors where it is not recruited directly (in trans; Brauweiler et al., 2007; Fortenbery et al., 2010). For example, CXCL12/CXCR4-induced calcium mobilization and cell migration is impaired by prior activation of Fc $\gamma$ RIIB and this inhibition is reduced in SHIP-deficient B cells (Brauweiler and Cambier, 2003; Brauweiler et al., 2007). Consistent with a role for SHIP-1 in inhibition, signaling through CXCR4 by CXCL12 is dependent on $\mathrm{PI}(3,4,5) \mathrm{P}_{3}$ (Brauweiler et al., 2007). Similarly, SHIP-1 acting in trans from the $2 \mathrm{~B} 4$ has been proposed to oppose $\mathrm{PI} 3 \mathrm{~K}$ activity at other receptors such as the MHC-I receptor in NK cells (Fortenbery et al., 2010).

It is also clear that SHIP-1 has a pivotal role in regulating the balance between pro-inflammatory and anti-inflammatory myeloid and lymphoid cells (Ghansah et al., 2004; Locke et al.,

Table 2 | Key receptors in the immune system that are known to recruit and/or be regulated by SHIP-1.

\begin{tabular}{|c|c|}
\hline Receptor & Reference \\
\hline B cell receptor & Okada et al. (1998) \\
\hline CD16 & Galandrini et al. (2002) \\
\hline CD22 & Poe et al. (2000) \\
\hline CD28 & Edmunds et al. (1999) \\
\hline TCR/CD3 complex & Dong et al. (2006) and Osborne et al. (1996) \\
\hline CXCR4 & Wain et al. (2005) \\
\hline Fce $R 1$ & $\begin{array}{l}\text { Gimborn et al. (2005), Huber et al. (1998), and } \\
\text { Kimura et al. (1997) }\end{array}$ \\
\hline Fc $\gamma$ RIla & Nakamura et al. (2002) \\
\hline Fc $\gamma R$ Rllb & Ono et al. (1996) \\
\hline $\begin{array}{l}\text { Granulocyte } \\
\text { colony-stimulating } \\
\text { factor receptor }\end{array}$ & Hunter and Avalos (1998) \\
\hline IL-3 receptor & Liu et al. (1999) \\
\hline KLRG1 & Tessmer et al. (2007) \\
\hline TLR2 & Keck et al. (2010) \\
\hline TLR3 & Gabhann et al. (2010) and Ruschmann et al. (2012) \\
\hline TLR4 & Keck et al. (2010) and Sly et al. (2004) \\
\hline TLR9 & Ruschmann et al. (2012) \\
\hline 2B4 & Wahle et al. (2007) \\
\hline
\end{tabular}

See main text for further details regarding whether SHIP-1 mediated negative or positive impact on signal transduction events elicited via each receptor. 
Table 3 | Impact of SHIP-1 gene targeting on leukocytes.

\begin{tabular}{|c|c|}
\hline Cell type & Phenotype of SHIP-1 KO \\
\hline Basophils & $\begin{array}{l}\text { SHIP-1 }{ }^{-/} \text {mice show increased Th2 skewing due to } \\
\text { increased IL-4 secretion from basophils (Kuroda et al., } \\
\text { 2011) }\end{array}$ \\
\hline B cell & $\begin{array}{l}\text { Btk membrane association increased. } \\
\text { Hyper-responsive to cross-linking of BCR (Bolland } \\
\text { et al., 1998; Helgason et al., 2000) } \\
\text { Loss of anergy, production of auto-antibodies (O'Neill } \\
\text { et al., 2011) }\end{array}$ \\
\hline Dendritic cell & $\begin{array}{l}\text { Enhanced survival and proliferation, but impaired } \\
\text { maturation (Antignano et al., 2010) } \\
\text { Reduced nitric oxide production; SHIP-1 null DC's } \\
\text { suppress T cell proliferation (Antignano et al., 2011) }\end{array}$ \\
\hline Mast cell & $\begin{array}{l}\text { Enhanced maturation of BMMC, CTMC, and MMC; } \\
\text { reduced IgE-induced BMMC survival; enhanced } \\
\text { degranulation of BMMCs, CTMC, and MMC } \\
\text { (Kalesnikoff et al., 2002; Ruschmann et al., 2012) } \\
\text { Enhanced TLR expression and TLR-induced cytokine } \\
\text { production from CTMCs via adaptor-mediated } \\
\text { pathway (Ruschmann et al., 2012) }\end{array}$ \\
\hline Myeloid cell & $\begin{array}{l}\text { Increased myeloid suppressor cell numbers (Ghansah } \\
\text { et al., 2004) } \\
\text { Increased } \mathrm{M} 2 \text { macrophage skewing (indirect } \\
\text { mechanism via increased IL-4 secretion from } \\
\text { basophils; Kuroda et al., 2009) } \\
\text { Increased ratio of PI(3,4,5) } \mathrm{P}_{3} \text { to } \mathrm{PI}(3,4) \mathrm{P}_{2} \text { on } \\
\text { phagosomal membrane. Decreased early NADPH } \\
\text { oxidative activity in phagosomes (Kamen et al., 2008) }\end{array}$ \\
\hline Natural killer cells & $\begin{array}{l}\text { Deficient receptor repertoire. Defective IFN } \gamma \\
\text { secretion. Increase in peripheral number. Defective } \\
\text { cytolytic function (Fortenbery et al., 2010) }\end{array}$ \\
\hline T cell & $\begin{array}{l}\text { Increased regulatory T cell differentiation, decreased } \\
\text { Th17 development (Locke et al., 2009) } \\
\text { Enhanced Th1 differentiation and CD8 cytotoxic } \\
\text { activity. Decreased Th2 differentiation (Tarasenko } \\
\text { et al., 2007) }\end{array}$ \\
\hline
\end{tabular}

N.B data is derived from germline SHIP-1 knock-out cells, except where denoted. ${ }^{a}$ The reported phenotype is derived from a T cell-specific SHIP-1 knock-out. $B M M C$, bone marrow-derived mast cells; CTMC, connective tissue mast cells; MMC, mucosal mast cells.

2009; Kuroda et al., 2011). For example, SHIP-1 deficient mice exhibit more myeloid-derived suppresser cells (MDSCs) than their wild type counterparts (Ghansah et al., 2004). Selective ablation of SHIP expression in either myeloid or T lymphoid lineage cells, has revealed that myeloid-specific ablation of SHIP leads to the expansion of both MDSC and Treg-cell numbers, indicating SHIPdependent control of Treg-cell numbers by a myeloid cell type. Conversely, T-lineage specific ablation of SHIP leads to expansion of Treg-cell numbers, but not expansion of the MDSC compartment, indicating SHIP also has a lineage intrinsic role in limiting Treg-cell numbers (Collazo et al., 2012). G-CSF is required for expansion of the MDSC splenic compartment in mice rendered
SHIP-deficient as adults. Thus, SHIP controls MDSC numbers, in part, by limiting production of the myelopoietic growth factor G-CSF (Collazo et al., 2012).

$\mathrm{SH} 2$ domain-containing inositol-5-phosphatase-1 also plays a role in regulating the balance of M1 macrophages (implicated in the first inflammatory response) and M2 macrophages (implicated in inflammatory response termination, tissue repair, regeneration, and remodeling). SHIP-1 deficiency leads to increased macrophage skewing toward M2 macrophages. This indicates that $\mathrm{PI}(3,4,5) \mathrm{P}_{3}$ drives macrophage progenitors toward an $\mathrm{M} 2$ phenotype and that SHIP-1 blocks this skewing (Rauh et al., 2005; Kuroda et al., 2009). Moreover, SHIP-1 is essential for normal Th17 cell development and plays a key role in the reciprocal regulation of Tregs and Th17 cells (Collazo et al., 2009; Locke et al., 2009). Germline SHIP deficiency promotes a preferential expansion and/or accumulation of conventional Tregs that have increased expression of FoxP3 indicating that SHIP limits Tregcell function in vivo and limits FoxP3 acquisition by naïve CD4 ${ }^{+}$ T cells (Collazo et al., 2009). Mice carrying a T cell-specific deletion of SHIP-1 uncovered a regulatory role for SHIP-1 in controlling $\mathrm{Th} 1 / \mathrm{Th} 2$ bias and cytotoxic responses as a result of its inhibitory effect on T-bet expression. Hence, SHIP-1 null T cells do not skew efficiently to a Th2 phenotype and display Th1-dominant immune responses in vitro and in vivo (Tarasenko et al., 2007). This is in contrast to evidence from germ line SHIP-1 null mice, which indicates that SHIP-1 can also repress Th2 skewing by inhibiting IL-4 production from basophils (Kuroda et al., 2011).

$\mathrm{T}$ cell-specific deletion of SHIP-1 using CD4CreSHIP ${ }^{\text {flox/flox }}$ mice, had no affect on T-cell development, activation state, or Treg-cell numbers (Tarasenko et al., 2007). However, a recent study using in LckCreSHIP flox/flox mice reported significant reduction in the frequency of splenic $\mathrm{CD}^{+}{ }^{+} \mathrm{T}$ cells and $\mathrm{CD} 4^{+}$and $\mathrm{CD} 8^{+}$ $\mathrm{T}$ cells in the peripheral blood relative to SHIP flox/flox controls (Collazo et al., 2012). The discrepancy may be because deletion of SHIP in CD4CreSHIP flox/flox mice may occur at a different time point during T-cell development compared to SHIP deletion in LckCreSHIP flox/flox mice.

\section{THE SHIP NAVY: A FORCE FOR DIVERSITY AND COMPLEXITY OF FUNCTION}

Multiple forms of the INPP5D gene product can occur via posttranslational modification, degradation, or alternative mRNA splicing. This produces SHIP-1 proteins of $145 \mathrm{kDa}(\mathrm{SHIP} \alpha)$, $135 \mathrm{kDa}$ (SHIP $\beta$ ), and $110 \mathrm{kDa}$ (SHIP $\delta$ ) in size. In addition, other 130,125 , and $110 \mathrm{kDa}$ forms of SHIP-1 have been reported (Hamilton et al., 2011; Kerr, 2011). Truncated SHIP-1 proteins exhibit differential protein binding properties owing to the lack of/altered expression of certain protein binding domains (Figure 3). For example, s-SHIP and its human homolog SIP-110, are truncated at the N-terminus and lack the $\mathrm{SH} 2$ domain, but retain the catalytic, $\mathrm{C} 2$ and proline rich domains. This limits the repertoire of binding proteins available for interaction and hence, these forms cannot interact with Shc, yet can still interact with Grb-2. Moreover, sSHIP is mostly localized at the plasma membrane rather than the cytoplasm (Hamilton et al., 2011; Kerr, 2011). Although originally thought to be restricted to embryonic stem cells, s-SHIP expression has been reported in adult hematopoietic cells and synergizes 
with SHIP-1 to regulate the activation of macrophages (Nguyen et al., 2011).

SHIP-2 is a $142-\mathrm{kDa}$ protein encoded by a separate gene, yet still retains approximately $65 \%$ homology with SHIP-1 within the catalytic domain. Divergence between SHIP-1 and SHIP-2 occurs largely within the proline rich domains as well as within the SH2 domain. In addition, SHIP-2 contains a unique sterile alpha motif (SAM) domain that can be involved in SAM-SAM domain interactions with other proteins, for example ARAP3 (Raaijmakers et al., 2007). SHIP-2 also shows the presence of an ubiquitin interacting motif at the C-terminal end and (unlike SHIP-1), it can hydrolyze $\mathrm{PI}(4,5) \mathrm{P}_{2}$ in vitro. SHIP-2 expression is not restricted to hematopoietic cell lineages and can be detected in heart, skeletal muscle, and brain tissues. SHIP-2 appears to have a major role in the negative regulation of insulin signaling in non-immune cells (Ooms et al., 2009). SHIP-1 and SHIP-2 are co-expressed in T cells and both are potent negative regulators of $\mathrm{PI}(3,4,5) \mathrm{P}_{3}$-mediated signals (Bruyns et al., 1999; Brauweiler et al., 2001). Tyrosine phosphorylation of SHIP-2 in T lymphocytes has not been reported, but it may still be enzymatically active and hence, the SHIP-1 knock-outs may have an incomplete phenotype. Interestingly, it is becoming clear that although SHIP-1 and SHIP-2 can interact with common binding partners, they additionally have their own unique profile of interacting partner proteins (Table 4), that possibly reflects the differences in their non-catalytic domains (Erneux et al., 2011; Mehta et al., 2011).
THE ROLE OF SHIP-1 IN HEMATOLOGICAL MALIGNANCIES Over-activation of PI3K-dependent signaling cascades is a common occurrence in many human cancers (Engelman, 2009). The lipid phosphatase PTEN which also negatively regulates $\mathrm{PI}(3,4,5) \mathrm{P}_{3}$ accumulation by de-phosphorylating the $\mathrm{D} 3$ position of the inositol ring, is a well characterized tumor suppressor gene (Hollander et al., 2011). Likewise, evidence for mutations of SHIP1 have also been shown in acute lymphoblastic leukemia (Luo et al., 2003) and in acute myeloid leukemia (Luo et al., 2004).

The loss of SHIP-1 has also been shown to promote the development of erythroleukemia, with SHIP-1 identified as a target gene of the oncogene fli-1 (Lakhanpal et al., 2010). There are at least two mechanisms by which SHIP-1 expression may be downregulated. The first involves targeting of SHIP- 1 by miR-155 in B cells, where high levels of miR-155 and reduced SHIP-1 expression have been linked to the development of acute lymphoblastic leukemia in mice (Costinean et al., 2009). miR-155 levels were also found to be significantly increased in human patients with diffuse large B cell lymphoma (Eis et al., 2005). The second involves BCR-ABL (the oncogene responsible for chronic myeloid leukemia), which either directly or via a Src kinase family member, tyrosine phosphorylates SHIP-1. This leads to polyubiquitination of SHIP-1 and subsequent STAT6 dependent-proteasomal degradation (Ruschmann et al., 2010). Interestingly, there is an inverse relationship between expression of SHIP-1 and BCR-ABL (Martino et al., 2001; Jiang et al., 2003). Thus, reduced SHIP-1

Table 4 | SHIP-1 and SHIP-2 interacting proteins.

\begin{tabular}{|c|c|c|}
\hline SHIP-1 interacting proteins & SHIP-2 interacting proteins & SHIP-1 and SHIP-2 interacting proteins \\
\hline CD2AP (Bao et al., 2012) & Actin, non-muscle ${ }^{a}$ (Mehta et al., 2011) & Btk $^{d}$ (Tomlinson et al., 2004b; Xie et al., 2008a) \\
\hline $\begin{array}{l}\text { Ezrin, Radaxin, and Meosin }{ }^{a} \\
\text { (Mehta et al., 2011) }\end{array}$ & APS $^{a}$ (Onnockx et al., 2008) & $\begin{array}{l}\text { CIN-85a,c (Havrylov et al., 2009; Buchse et al., } \\
\text { 2011) }\end{array}$ \\
\hline FUBP2 ${ }^{a}$ (Mehta et al., 2011) & ARAP3 $^{\text {b }}$ (Raaijmakers et al., 2007) & $\begin{array}{l}\text { DOk1a (Tamir et al., 2000; Havrylov et al., } \\
\text { 2009; Cunningham et al., 2010) }\end{array}$ \\
\hline Grb-2ª (Mehta et al., 2011) & c-Cbl ${ }^{b}$ Nandenbroere et al., 2003) & $\begin{array}{l}\text { Filamin }^{a, c} \text { (Dyson et al., 2001; Lesourne et al., } \\
\text { 2005) }\end{array}$ \\
\hline KLRG1a (Tessmer et al., 2007) & Glucose-regulated protein precursora (Mehta et al., 2011) & Shca (Mehta et al., 2011) \\
\hline LyGDIa (Mehta et al., 2011) & Heat shock protein 90-betaa (Mehta et al., 2011) & Tec $^{d}$ (Tomlinson et al., 2004a) \\
\hline PKC- $\delta^{a}$ (Chari et al., 2009) & Hematopoietic cell specific Lyn substrate ${ }^{a}$ (Mehta et al., 2011) & \\
\hline \multirow[t]{9}{*}{ PLC- $\gamma 1^{a}$ (Song et al., 2005) } & HSP90 $\beta^{a}$ (Mehta et al., 2011) & \\
\hline & Intersectin $1^{\text {b }}$ (Xie et al., 2008b) & \\
\hline & Protein disulfide-isomerase A3 precursora Mehta et al., 2011) & \\
\hline & PR130` (Zwaenepoel et al., 2010) & \\
\hline & PTP1B ${ }^{c}$ (Mertins et al., 2008) & \\
\hline & p130Cas ${ }^{a}$ (Prasad et al., 2001) & \\
\hline & JIP1 ${ }^{b}$ (Xie et al., 2008a) & \\
\hline & Tubulin beta-2A chain ${ }^{a}$ (Mehta et al., 2011) & \\
\hline & Vinexinc (Paternotte et al., 2005) & \\
\hline
\end{tabular}

Methods by which interactions have been identified are indicated: a immunoprecipitation; ${ }^{b}$ yeast two hybrid; ${ }^{\circ}$ mass spectrometry; ${ }^{a}$ GST-SH3 pull-down. Where known, the domains within SHIP-1 that interact with these proteins are indicated in Figure 3. Protein interactions with SHIP-1 that are known to result in positive signaling outcomes are indicated in red. Refer to main text for further detail.

ARAP3, Arf-GAP, Rho-GAP, ankyrin repeat and PH domain-3; CIN85, Cbl-interacting 85 kDa protein; FUBP2, far upstream element binding protein-2; JIP1, c-Jun NH 2 terminal kinase (JNK)-interacting protein-1; KLRG1, killer cell lectin-like receptor G1; LyGDI, a Rho guanine nucleotide dissociation inhibitor originally identified in lymphocytes; PTPB1, protein-tyrosine phosphatase $1 B$. 
activity might be a prerequisite for the proliferative advantage of some chronic myeloid leukemia clones. A similar inverse relationship exists between a constitutively active oncogenic c-kit receptor and SHIP-1, whereby inhibition of c-kit's intrinsic tyrosine kinase activity with Imatinib reversibly raises SHIP-1 levels (Vanderwinden et al., 2006).

The role of SHIP-1 as a tumor suppressor is also evident in the ability of SHIP-1 to restrict myeloid suppressor cells and regulatory T cells (Ghansah et al., 2004; Locke et al., 2009). Therefore the loss of SHIP-1 expression/function may lead to increased suppression of T-cell mediated anti-tumor immunity. Indeed, in murine pancreatic cancer SHIP-1 expression was shown to be reduced in splenocytes which also correlated with an increase in myeloid suppressor cell numbers (Pilon-Thomas et al., 2011). Decreased SHIP1 expression has also been shown in myelodysplastic syndrome progenitor cells, whereas over-expression of SHIP-1 inhibited myeloid leukemic growth (Lee et al., 2012).

The role of SHIP-1 in leukemia however, appears more complex than initially thought. For example, while PTEN can suppress growth and apoptosis, SHIP-1 was shown not to act as a tumor suppressor in myeloma cells (Choi et al., 2002). The use of a small molecule SHIP-1 inhibitor demonstrated that catalytically active SHIP-1 is required for the survival of multiple myeloma cells (Brooks et al., 2010) and that therefore, in certain cases, SHIP-1 actually supports cancer cell survival. This would be consistent with increased levels of the SHIP-1 enzymatic product $\mathrm{PI}(3,4) \mathrm{P}_{2}$ promoting Akt activation and survival/proliferation (Manning and Cantley, 2007). Indeed, another group has shown that SHIP-1 inhibits CD95/Fas-mediated apoptosis of T cells, albeit independently of its catalytic activity (Charlier et al., 2010).

\section{SHIP-1 AND THE STEM CELL NICHE}

The crucial role of PTEN/Akt in the maintenance of stem cell homeostasis is now evident (Hill and Wu, 2009; Song et al., 2012). It is now becoming clear that SHIP-1 also has an important role in maintaining the stem cell niche. Hemopoietic stem cell (HSC) proliferation is increased in SHIP-1 null mice. Despite expansion of the compartment, SHIP-1 deficient HSCs exhibit reduced capacity for long-term repopulation and home inefficiently to bone marrow (Desponts et al., 2006; Hazen et al., 2009). The role of SHIP-1 in the biology of both HSC and the hematopoietic stem cell niche, suggests that it may be a useful target for treatment of bone marrow failure syndromes caused by viruses, radiation, chemotherapy, or malignancy. As already mentioned, MDSCs are a type of immunoregulatory cell that can repress allogeneic $\mathrm{T}$ cell responses. A common complication arising after bone marrow transplantation is Graft-versus-host disease (GVHD) which involves priming of allogeneic $\mathrm{T}$ cells. Remarkably, SHIP-1 deficient mice express more myeloid suppressor cells than their wild type counterparts and accept allogeneic bone marrow grafts with a reduced incidence of GVHD (Ghansah et al., 2004; Kerr, 2008). In addition SHIP-1 null mice are better able to accept bone marrow transplants compared to controls (Wang et al., 2002) and SHIP-1 deficient mice have shown reduced cardiac graft rejection compared to controls (Collazo et al., 2009).

\section{SHIP IS TARGETED BY PATHOGENS TO AVOID IMMUNE RECOGNITION}

The key regulatory role of SHIP-1 has been exploited by several opportunistic pathogens that target these phosphatases in order to evade immune detection. Thus, lymphocytes are particularly sensitive to the cytolethal distending toxin subunit B (CdtB), an immunotoxin produced by Actinobacillus actinomycetemcomitans, that can hydrolyze $\mathrm{PI}(3,4,5) \mathrm{P}_{3}$ to $\mathrm{PI}(3,4) \mathrm{P}_{2}$. Exposure to CdtB leads to cell cycle arrest and death by apoptosis. The lipid phosphatase activity of $\mathrm{CdtB}$ may therefore, result in reduced immune function, facilitating chronic infection with Actinobacillus and other enteropathogens that express Cdt proteins (Shenker et al., 2007). The measles virus evades destruction by the immune system, at least in part, by targeting negative regulation of PI3K/Akt signaling. It induces expression of the SHIP-1 homolog SIP110 which depletes cellular $\mathrm{PI}(3,4,5) \mathrm{P}_{3}$ pools, suggesting that the threshold for activation signals leading to induction of $\mathrm{T}$ cell proliferation is raised (Avota et al., 2006). The targeting of this protein by pathogens to avoid immune recognition, emphasizes the notion that SHIP-1 might offer opportunities for the design of new drugs targeting PI3K-dependent signaling.

\section{PHARMACOLOGICAL MANIPULATION OF SHIP ALLOSTERIC SHIP-1 ACTIVATORS}

In 2005, pelorol (a product of the marine invertebrate Dactylospongia elegans) was described as an activator of SHIP-1 (Yang et al., 2005). More potent synthetic chemical entities have since been designed by Aquinox Pharmaceuticals (Figure 1). Along with $\mathrm{PI}(3,4) \mathrm{P}_{2}$, these compounds were shown to allosterically enhance catalytic activity by binding to the $\mathrm{C} 2$ domain of SHIP1 (Figure 3). The C2 domains of SHIP-1 and SHIP-2 share 38\% homology (compared to 51\% homology between total SHIP-1 and SHIP-2 in humans), and it is believed that this reduced homology in the $\mathrm{C} 2$ domain allows these pelorol based compounds to achieve SHIP-1 selectivity. This is particularly important given the crucial role of SHIP-2 in the regulation of insulin signaling (Ooms et al., 2009). Two of these compounds, AQX-016A and AQX-MN100, exhibited potent inhibition of immune cell activation in vitro and were anti-inflammatory in vivo using mouse models of endotoxemia and acute cutaneous anaphylaxis (Ong et al., 2007). Intriguingly, these SHIP-1 activating compounds increased apoptosis of multiple myeloma cells in vitro and when used in combination with bortezomib (an established multiple myeloma treatment) proved more effective at inhibiting cancer cell proliferation than bortezomib alone (Kennah et al., 2009). Other compounds based on the structure of pelorol have been developed by Aquinox Pharmaceuticals as SHIP-1 activating compounds with a view for application in inflammatory disorders. AQX-1125 is the most advanced and has passed Phase 1 clinical trials in 2011, with Phase IIa clinical studies initiated in late 2011 for the treatment of mild and moderate asthma (Table 1). With regard to the latter, the recent finding that TLR stimulation augments IgE plus Ag-induced TNFa and IL-6 production from MMCs (Ruschmann et al., 2012) might explain the exacerbation of IgE-mediated allergic episodes by infectious agents (Qiao et al., 2006). Since IgE synergizes with TLR ligands to trigger cytokine production from SHIP-1 null mucosal mast cells, 
activating SHIP-1 specifically in these cells might be useful for treating chronic inflammatory diseases like asthma.

\section{SHIP-1 INHIBITORS}

A novel small molecule selective inhibitor of SHIP-1, termed $3 \alpha$ aminocholestane (3AC, Figure 1) has also recently been identified using high-throughput screening, though the site of drug-protein interaction is unclear (Brooks et al., 2010). Consistent with observations from SHIP-1 deficient mice, treatment of mice with $3 \mathrm{AC}$ led to increased numbers of myeloid suppressor cells and reduced ability of peripheral lymphoid tissues to prime myeloid-associated responses and protected against GVHD (Brooks et al., 2010). The inhibition of SHIP-1 using pharmacological compounds may therefore offer the potential to aid transplant acceptance in patients undergoing transplant surgery. 3AC also increased levels of granulocytes, red blood cells, neutrophils, and platelets in mice and could therefore, have potential to improve blood cell number in patients with myelodysplastic syndrome or myelosuppressive infection.

Remarkably, SHIP-1 inhibition using 3AC induced the apoptosis of human acute myeloid leukemia cell lines which is consistent with SHIP-1 being anti-apoptotic under some circumstances (Brooks et al., 2010). Further studies showed that 3AC inhibited multiple myeloma cell growth in a tumor xenograft model in mice (Fuhler et al., 2011). Since both substrate $\left[\mathrm{PI}(3,4,5) \mathrm{P}_{3}\right]$ and product $\left[\mathrm{PI}(3,4) \mathrm{P}_{2}\right]$ of SHIP-1 have been shown to influence Akt activation and cell survival, this may explain in part, why both activators and inhibitors of SHIP-1 have shown efficacy against leukemic cells (Kerr, 2011).

\section{SHIP-2 INHIBITORS}

SHIP-2 is thought to be involved in type-2 diabetes and obesity (Ooms et al., 2009) as well as cancer and atherosclerosis (Suwa et al., 2010). The development of compounds which selectively target SHIP-2 has therefore been of great interest. Small molecule compounds which specifically inhibit the catalytic activity of SHIP-2 have recently been described (Suwa et al., 2009). In addition a novel biphenyl $2,3^{\prime} 4,5^{\prime}, 6$-pentakisphosphate $\left[\operatorname{BiPh}\left(2,3^{\prime}, 4,5^{\prime}, 6\right) \mathrm{P}_{5}\right]$ compound has demonstrated potent inhibition of SHIP-2 catalytic activity (Vandeput et al., 2007). $\operatorname{BiPh}\left(2,3^{\prime}, 4,5^{\prime}, 6\right) \mathrm{P}_{5}$ in its current form is however not cell permeable and therefore does not possess drug-like properties. The crystal structure of the phosphatase domain of SHIP-2 bound to $\operatorname{BiPh}\left(2,3^{\prime}, 4,5^{\prime}, 6\right) \mathrm{P}_{5}$ has identified a flexible loop which folds over and encloses the ligand (Mills et al., 2012) and may have

\section{REFERENCES}

Anderson, K. E., Boyle, K. B., Davidson, K., Chessa, T. A., Kulkarni, S., Jarvis, G. E., Sindrilaru, A., ScharffetterKochanek, K., Rausch, O., Stephens, L. R., and Hawkins, P. T. (2008). CD18-dependent activation of the neutrophil NADPH oxidase during phagocytosis of Escherichia coli or Staphylococcus aureus is regulated by class III but not class I or II PI3Ks. Blood 112, 5202-5211.
Antignano, F., Hamilton, M., Patterson, S., Ho, V., Cohen, C., Levings, M. K., and Krystal, G. (2011). SHIP-deficient dendritic cells, unlike wild type dendritic cells, suppress $\mathrm{T}$ cell proliferation via a nitric oxide-independent mechanism. PLoS ONE 6, e21893. doi:10.1371/journal.pone.0021893

Antignano, F., Ibaraki, M., Kim, C., Ruschmann, J., Zhang, A., Helgason, C. D., and Krystal, G. (2010).

implications for development of small molecules that target SHIP-1. The targeting of this region may allow more SHIP2 specific drugs to be developed. Cell permeable pan-SHIP$1 / 2$ inhibitors have also recently been identified and have been reported to kill multiple myeloma cells (Fuhler et al., 2011). The development of SHIP-2 specific compounds suggests that SHIP-2 may be a potential target with which to treat a range of diseases, in addition to allowing the poorly understood role of SHIP-2 in the immune system, to be probed in greater depth.

\section{SUMMARY}

The difficulties of developing PI3K $\gamma$ inhibitors with sufficient selectivity over other PI3K isoforms has in part, led to the search for alternative drug targets to selectively modify PI3K signaling in the immune system. This search revealed the potential for exploiting the lipid phosphatase SHIP-1, an endogenous and leukocyterestricted regulator of PI3K signaling. Small molecule regulators of this protein have shown early promise in inflammatory, transplantation, and cancer settings, and are currently in phase IIa clinical trials to evaluate the safety, tolerability, and pharmacokinetics (Table 1). The selectivity profile of compounds targeting SHIP-1 is at present quite limited and while they appear to exhibit specificity for SHIP-1 versus SHIP-2 and PTEN, it remains to be seen whether there are other off-target effects. Despite this early promise, the targeting of SHIP-1 (particularly with inhibitors), is not without its potential problems. For example, SHIP-1 deficiency leads to a number of pathologies including fibrotic lung disease (Rauh et al., 2005), osteoporosis (Moon et al., 2011), and the development of spontaneous intestinal inflammation and fibrosis (Kerr et al., 2011; McLarren et al., 2011). An important factor to consider is that targeting catalytic activity may not be sufficient to inhibit all SHIP-1 mediated effects, given that SHIP-1 also fulfills key non-catalytic scaffolding functions (Song et al., 2005; Peng et al., 2010; Bao et al., 2012; Ruschmann et al., 2012). Hence, small molecule-based strategies to target catalytic activity are unlikely to affect these non-catalytic functions. This may be beneficial on the one hand, if pathological consequences are dependent on catalytic functions as such approaches will likely retain the non-enzymatic functions and hopefully limit unwanted side-effects. On the other hand, such strategies may be ineffective if pathological consequences are driven by non-enzymatic functions of SHIP-1. It is interesting to note however, that prolonged inhibition of SHIP-1 with $3 \mathrm{AC}$ leads to proteasome-dependent degradation of SHIP-1 (Fuhler et al., 2011).

SHIP is required for dendritic cell maturation. J. Immunol. 184, 2805-2813.

Avota, E., Harms, H., and SchneiderSchaulies, S. (2006). Measles virus induces expression of SIP110, a constitutively membrane clustered lipid phosphatase, which inhibits T cell proliferation. Cell. Microbiol. 8, 1826-1839.

Backer, J. M. (2008). The regulation and function of Class III PI3Ks: novel roles for Vps34. Biochem. J. 410, $1-17$.

Bao, M., Hanabuchi, S., Facchinetti, V., Du, Q., Bover, L., Plumas, J., Chaperot, L., Cao, W., Qin, J., Sun, S. C., and Liu, Y. J. (2012). CD2AP/SHIP1 complex positively regulates plasmacytoid dendritic cell receptor signaling by inhibiting the E3 ubiquitin ligase Cbl. J. Immunol. 189, 786-792.

Barber, D. F., Bartolome, A., Hernandez, C., Flores, J. M., Redondo, 
C., Fernandez-Arias, C., Camps, M., Ruckle, T., Schwarz, M. K., Rodriguez, S., Martinez, A. C., Balomenos, D., Rommel, C., and Carrera, A. C. (2005). PI3Kgamma inhibition blocks glomerulonephritis and extends lifespan in a mouse model of systemic lupus. Nat. Med. 11, 933-935.

Bergamini, G., Bell, K., Shimamura, S., Werner, T., Cansfield, A., Muller, K., Perrin, J., Rau, C., Ellard, K., Hopf, C., Doce, C., Leggate, D., Mangano, R., Mathieson, T., O’Mahony, A., Plavec, I., Rharbaoui, F., Reinhard, F., Savitski, M. M., Ramsden, N., Hirsch, E., Drewes, G., Rausch, O., Bantscheff, M., and Neubauer, G. (2012). A selective inhibitor reveals PI3Kgamma dependence of $\mathrm{T}(\mathrm{H}) 17$ cell differentiation. Nat. Chem. Biol. 8, 576-582.

Berndt, A., Miller, S., Williams, O., Le, D. D., Houseman, B. T., Pacold, J. I., Gorrec, F., Hon, W. C., Liu, Y., Rommel, C., Gaillard, P., Rückle, T., Schwarz, M. K., Shokat, K. M., Shaw, J. P., and Williams, R. L. (2010). The p110 delta structure: mechanisms for selectivity and potency of new PI(3)K inhibitors. Nat. Chem. Biol. 6, 117-124.

Bird, J. E., Smith, P. L., Bostwick, J. S., Shipkova, P., and Schumacher, W. A. (2011). Bleeding response induced by anti-thrombotic doses of a phosphoinositide 3-kinase (PI3K)-beta inhibitor in mice. Thromb. Res. 127, 560-564.

Bolland, S., Pearse, R. N., Kurosaki, T., and Ravetch, J. V. (1998). SHIP modulates immune receptor responses by regulating membrane association of Btk. Immunity 8, 509-516.

Boyle, K. B., Gyori, D., Sindrilaru, A., Scharffetter-Kochanek, K., Taylor, P. R., Mocsai, A., Stephens, L. R., and Hawkins, P. T. (2011). Class IA phosphoinositide 3-kinase beta and delta regulate neutrophil oxidase activation in response to Aspergillus fumigatus hyphae. J. Immunol. 186, 2978-2989.

Brauweiler, A., Merrell, K., Gauld, S. B., and Cambier, J. C. (2007). Cutting edge: acute and chronic exposure of immature B cells to antigen leads to impaired homing and SHIP1dependent reduction in stromal cellderived factor-1 responsiveness. J. Immunol. 178, 3353-3357.

Brauweiler, A., Tamir, I., Marschner, S., Helgason, C. D., and Cambier, J. C. (2001). Partially distinct molecular mechanisms mediate inhibitory FcgammaRIIB signaling in resting and activated B cells. J. Immunol. 167, 204-211.
Brauweiler, A. M., and Cambier, J. C. (2003). Fc gamma RIIB activation leads to inhibition of signalling by independently ligated receptors. Biochem. Soc. Trans. 31, 281-285.

Brooks, R., Fuhler, G. M., Iyer, S., Smith, M. J., Park, M. Y., Paraiso, K. H., Engelman, R. W., and Kerr, W. G. (2010). SHIP1 inhibition increases immunoregulatory capacity and triggers apoptosis of hematopoietic cancer cells. J. Immunol. 184, 3582-3589.

Bruyns, C., Pesesse, X., Moreau, C., Blero, D., and Erneux, C. (1999). The two SH2-domain-containing inositol 5-phosphatases SHIP1 and SHIP2 are coexpressed in human T lymphocytes. Biol. Chem. 380, 969-974.

Buchse, T., Horras, N., Lenfert, E., Krystal, G., Korbel, S., Schumann, M., Krause, E., Mikkat, S., and Tiedge, M. (2011). CIN85 interacting proteins in B cells-specific role for SHIP-1. Mol. Cell Proteomics 10, M110.006239.

Camps, M., Ruckle, T., Ji, H., Ardissone, V., Rintelen, F., Shaw, J., Ferrandi, C., Chabert, C., Gillieron, C., Francon, B., Martin, T., Gretener, D., Perrin, D., Leroy, D., Vitte, P. A., Hirsch, E., Wymann, M. P., Cirillo, R., Schwarz, M. K., and Rommel, C. (2005). Blockade of PI3Kgamma suppresses joint inflammation and damage in mouse models of rheumatoid arthritis. Nat. Med. 11, 936-943.

Chari, R., Kim, S., Murugappan, S., Sanjay, A., Daniel, J. L., and Kunapuli, S. P. (2009). Lyn, PKCdelta, SHIP-1 interactions regulate GPVI-mediated platelet-dense granule secretion. Blood 114, 3056-3063.

Charlier, E., Conde, C., Zhang, J., Deneubourg, L., di Valentin, E., Rahmouni, S., Chariot, A., Agostinis, P., Pang, P. C., Haslam, S. M., Dell, A., Penninger, J., Erneux, C., Piette, J., and Gloire, G. (2010). SHIP-1 inhibits CD95/APO-1/Fas-induced apoptosis in primary $\mathrm{T}$ lymphocytes and $\mathrm{T}$ leukemic cells by promoting CD95 glycosylation independently of its phosphatase activity. Leukemia 24, 821-832.

Choi, Y., Zhang, J., Murga, C., Yu, H., Koller, E., Monia, B. P., Gutkind, J. S., and Li, W. (2002). PTEN, but not SHIP and SHIP2, suppresses the PI3K/Akt pathway and induces growth inhibition and apoptosis of myeloma cells. Oncogene 21, 5289-5300.

Collazo, M. M., Paraiso, K. H., Park, M. Y., Hazen, A. L., and Kerr, W. G. (2012). Lineage extrinsic and intrinsic control of immunoregulatory cell numbers by SHIP. Eur. J. Immunol. doi:10.1002/eji.201142092

Collazo, M. M., Wood, D., Paraiso, K. H., Lund, E., Engelman, R. W., Le, C. T., Stauch, D., Kotsch, K., and Kerr, W. G. (2009). SHIP limits immunoregulatory capacity in the T-cell compartment. Blood 113, 2934-2944.

Costantini, J. L., Cheung, S. M., Hou, S., Li, H., Kung, S. K., Johnston, J. B., Wilkins, J. A., Gibson, S. B., and Marshall, A. J. (2009). TAPP2 links phosphoinositide 3-kinase signaling to B-cell adhesion through interaction with the cytoskeletal protein utrophin: expression of a novel cell adhesion-promoting complex in B-cell leukemia. Blood 114, 4703-4712.

Costinean, S., Sandhu, S. K., Pedersen, I. M., Tili, E., Trotta, R., Perrotti, D., Ciarlariello, D., Neviani, P., Harb, J., Kauffman, L. R., Shidham, A., and Croce, C. M. (2009). Src homology 2 domain-containing inositol-5phosphatase and CCAAT enhancerbinding protein beta are targeted by miR-155 in B cells of EmicroMiR-155 transgenic mice. Blood 114, 1374-1382.

Crabbe, T., Welham, M. J., and Ward, S. G. (2007). The PI3K inhibitor arsenal: choose your weapon! Trends Biochem. Sci. 32, 450-456.

Cunningham, D. L., Sweet, S. M., Cooper, H. J., and Heath, J. K. (2010). Differential phosphoproteomics of fibroblast growth factor signaling: identification of Src family kinasemediated phosphorylation events. $J$. Proteome Res. 9, 2317-2328.

Desponts, C., Hazen, A. L., Paraiso, K. H., and Kerr, W. G. (2006). SHIP deficiency enhances HSC proliferation and survival but compromises homing and repopulation. Blood 107, 4338-4345.

Dong, S., Corre, B., Foulon, E., Dufour E., Veillette, A., Acuto, O., and Michel, F. (2006). T cell receptor for antigen induces linker for activation of $\mathrm{T}$ cell-dependent activation of a negative signaling complex involving Dok-2, SHIP-1, and Grb-2. J. Exp. Med. 203, 2509-2518.

Doukas, J., Eide, L., Stebbins, K., Racanelli-Layton, A., Dellamary, L., Martin, M., Dneprovskaia, E., Noronha, G., Soll, R., Wrasidlo, W., Acevedo, L. M., and Cheresh, D. A. (2009). Aerosolized phosphoinositide 3-kinase gamma/delta inhibitor TG100-115 [3-[2,4-diamino-6-(3hydroxyphenyl)pteridin-7-yl]phen ol] as a therapeutic candidate for asthma and chronic obstructive pulmonary disease. J. Pharmacol. Exp. Ther. 328, 758-765.
Doukas, J., Wrasidlo, W., Noronha, G., Dneprovskaia, E., Fine, R., Weis, S., Hood, J., Demaria, A., Soll, R., and Cheresh, D. (2006). Phosphoinositide 3-kinase gamma/delta inhibition limits infarct size after myocardial ischemia/reperfusion injury Proc. Natl. Acad. Sci. U.S.A. 103 19866-19871.

Dowler, S., Currie, R. A., Campbell, D. G., Deak, M., Kular, G., Downes, C. P., and Alessi, D. R. (2000). Identification of pleckstrinhomology-domain-containing proteins with novel phosphoinositidebinding specificities. Biochem. J. 351, 19-31.

Dyson, J. M., O’Malley, C. J., Becanovic, J., Munday, A. D., Berndt, M. C., Coghill, I. D., Nandurkar, H. H., Ooms, L. M., and Mitchell, C. A. (2001). The SH2-containing inositol polyphosphate 5-phosphatase, SHIP-2, binds filamin and regulates submembraneous actin. J. Cell Biol. 155, 1065-1079.

Edmunds, C., Parry, R. V., Burgess, S. J., Reaves, B., and Ward, S. G. (1999). CD28 stimulates tyrosine phosphorylation, cellular redistribution and catalytic activity of the inositol lipid 5-phosphatase SHIP. Eur. J. Immunol. 29, 3507-3515.

Eis, P. S., Tam, W., Sun, L., Chadburn, A., Li, Z., Gomez, M. F., Lund, E., and Dahlberg, J. E. (2005). Accumulation of miR-155 and BIC RNA in human B cell lymphomas. Proc. Natl. Acad. Sci. U.S.A. 102, 3627-3632.

Ellson, C., Davidson, K., Anderson, K., Stephens, L. R., and Hawkins, P. T. (2006). PtdIns3P binding to the PX domain of p40phox is a physiological signal in NADPH oxidase activation. EMBO J. 25, 4468-4478.

Engelman, J. A. (2009). Targeting PI3K signalling in cancer: opportunities, challenges and limitations. Nat. Rev. Cancer 9, 550-562.

Erneux, C., Edimo, W. E., Deneubourg, L., and Pirson, I. (2011). SHIP2 multiple functions: a balance between a negative control of PtdIns(3,4,5)P3 level, a positive control of PtdIns(3,4)P2 production, and intrinsic docking properties. J. Cell. Biochem. 112, 2203-2209.

Fortenbery, N. R., Paraiso, K. H., Taniguchi, M., Brooks, C., Ibrahim, L., and Kerr, W. G. (2010). SHIP influences signals from CD48 and MHC class I ligands that regulate NK cell homeostasis, effector function, and repertoire formation. J. Immunol. 184, 5065-5074.

Fratti, R. A., Backer, J. M., Gruenberg, J., Corvera, S., and Deretic, 
V. (2001). Role of phosphatidylinositol 3-kinase and Rab5 effectors in phagosomal biogenesis and mycobacterial phagosome maturation arrest. J. Cell Biol. 154, 631-644.

Fruman, D. A., and Rommel, C. (2011). PI3Kdelta inhibitors in cancer: rationale and serendipity merge in the clinic. Cancer Discov. 1, 562-572.

Fuhler, G. M., Brooks, R., Toms, B., Iyer, S., Gengo, E. A., Park, M. Y., Gumbleton, M., Viernes, D. R., Chisholm, J. D., and Kerr, W. G. (2011). Therapeutic potential of SHIP1 and SHIP2 inhibition in cancer cells. Mol. Med. $18,65-75$.

Gabhann, J. N., Higgs, R., Brennan, K., Thomas, W., Damen, J. E., Ben Larbi, N., Krystal, G., and Jefferies, C. A. (2010). Absence of SHIP-1 results in constitutive phosphorylation of tank-binding kinase 1 and enhanced TLR3-dependent IFN-beta production. J. Immunol. 184, 2314-2320.

Galandrini, R., Tassi, I., Mattia, G., Lenti, L., Piccoli, M., Frati, L., and Santoni, A. (2002). SH2-containing inositol phosphatase (SHIP-1) transiently translocates to raft domains and modulates CD16-mediated cytotoxicity in human NK cells. Blood 100, 4581-4589.

Ghansah, T., Paraiso, K. H., Highfill, S., Desponts, C., May, S., McIntosh, J. K., Wang, J. W., Ninos, J., Brayer, J., Cheng, F., Sotomayor, E., and Kerr, W. G. (2004). Expansion of myeloid suppressor cells in SHIPdeficient mice represses allogeneic $\mathrm{T}$ cell responses. J. Immunol. 173, 7324-7330.

Gimborn, K., Lessmann, E., Kuppig, S., Krystal, G., and Huber, M. (2005). SHIP down-regulates FcepsilonR1induced degranulation at supraoptimal IgE or antigen levels. J. Immunol. $174,507-516$.

Guillermet-Guibert, J., Bjorklof, K., Salpekar, A., Gonella, C., Ramadani, F., Bilancio, A., Meek, S., Smith, A. J., Okkenhaug, K., and Vanhaesebroeck, B. (2008). The p110beta isoform of phosphoinositide 3-kinase signals downstream of $\mathrm{G}$ proteincoupled receptors and is functionally redundant with pllogamma. Proc. Natl. Acad. Sci. U.S.A. 105, 8292-8297.

Hamilton, M. J., Ho, V. W., Kuroda, E., Ruschmann, J., Antignano, F., Lam, V., and Krystal, G. (2011). Role of SHIP in cancer. Exp. Hematol. 39, 2-13.

Harris, S. J., Parry, R. V., Foster, J. G., Blunt, M. D., Wang, A., MarelliBerg, F., Westwick, J., and Ward, S. G. (2011). Evidence that the lipid phosphatase SHIP-1 regulates $\mathrm{T}$ lymphocyte morphology and motility. J. Immunol. 186, 4936-4945.

Harris, S. J., Parry, R. V., Westwick, J., and Ward, S. G. (2008). Phosphoinositide lipid phosphatases: natural regulators of phosphoinositide 3kinase signaling in $\mathrm{T}$ lymphocytes. J. Biol. Chem. 283, 2465-2469.

Havrylov, S., Rzhepetskyy, Y., Malinowska, A., Drobot, L., and Redowicz, M. J. (2009). Proteins recruited by $\mathrm{SH} 3$ domains of Ruk/CIN85 adaptor identified by LC-MS/MS. Proteome Sci. 7, 21.

Hazen, A. L., Smith, M. J., Desponts, C., Winter, O., Moser, K., and Kerr, W. G. (2009). SHIP is required for a functional hematopoietic stem cell niche. Blood 113, 2924-2933.

Helgason, C. D., Kalberer, C. P., Damen, J. E., Chappel, S. M., Pineault, N., Krystal, G., and Humphries, R. K. (2000). A dual role for Src homology 2 domain-containing inositol5-phosphatase (SHIP) in immunity: aberrant development and enhanced function of B lymphocytes in $\mathrm{SHIP}^{-/-}$mice. J. Exp. Med. 191, 781-794.

Herman, S. E., Gordon, A. L., Wagner, A. J., Heerema, N. A., Zhao, W., Flynn, J. M., Jones, J., Andritsos, L., Puri, K. D., Lannutti, B. J., Giese, N. A., Zhang, X., Wei, L., Byrd, J. C., and Johnson, A. J. (2010). Phosphatidylinositol 3-kinase-delta inhibitor CAL-101 shows promising preclinical activity in chronic lymphocytic leukemia by antagonizing intrinsic and extrinsic cellular survival signals. Blood 116, 2078-2088.

Hill, R., and Wu, H. (2009). PTEN, stem cells, and cancer stem cells. J. Biol. Chem. 284, 11755-11759.

Hoellenriegel, J., Meadows, S. A., Sivina, M., Wierda, W. G., Kantarjian, H., Keating, M. J., Giese, N., O’Brien, S., Yu, A., Miller, L. L., Lannutti, B. J., and Burger, J. A. (2011). The phosphoinositide $3^{\prime}$ kinase delta inhibitor, CAL-101, inhibits B-cell receptor signaling and chemokine networks in chronic lymphocytic leukemia. Blood 118, 3603-3612.

Hollander, M. C., Blumenthal, G. M., and Dennis, P. A. (2011). PTEN loss in the continuum of common cancers, rare syndromes and mouse models. Nat. Rev. Cancer 11, 289-301.

Huber, M., Helgason, C. D., Damen, J. E., Liu, L., Humphries, R. K., and Krystal, G. (1998). The srchomology 2-containing inositol phosphatase (SHIP) is the gatekeeper of mast cell degranulation. Proc. Natl. Acad. Sci. U.S.A. 95, 11330-11335.
Hunter, M. G., and Avalos, B. R. (1998). Phosphatidylinositol $3^{\prime}$ kinase and $\mathrm{SH} 2$-containing inositol phosphatase (SHIP) are recruited by distinct positive and negative growth-regulatory domains in the granulocyte colony-stimulating factor receptor. J. Immunol. 160, 4979-4987.

Ikeda, H., Hideshima, T., Fulciniti, M., Perrone, G., Miura, N., Yasui, H., Okawa, Y., Kiziltepe, T., Santo, L., Vallet, S., Cristea, D., Calabrese, E. Gorgun, G., Raje, N. S., Richardson, P., Munshi, N. C., Lannutti, B. J., Puri, K. D., Giese, N. A., and Anderson, K. C. (2010). PI3K/p110\{delta\} is a novel therapeutic target in multiple myeloma. Blood 116, 1460-1468.

Jiang, X., Stuible, M., Chalandon, Y., Li, A., Chan, W. Y., Eisterer, W., Krystal, G., Eaves, A., and Eaves, C. (2003). Evidence for a positive role of SHIP in the BCR-ABL-mediated transformation of primitive murine hematopoietic cells and in human chronic myeloid leukemia. Blood 102, 2976-2984.

Kalesnikoff, J., Lam, V., and Krystal, G. (2002). SHIP represses mast cell activation and reveals that $\operatorname{IgE}$ alone triggers signaling pathways which enhance normal mast cell survival. Mol. Immunol. 38, 1201-1206.

Kamen, L. A., Levinsohn, J., Cadwallader, A., Tridandapani, S., and Swanson, J. A. (2008). SHIP-1 increases early oxidative burst and regulates phagosome maturation in macrophages. J. Immunol. 180 7497-7505.

Keck, S., Freudenberg, M., and Huber M. (2010). Activation of murine macrophages via TLR2 and TLR4 is negatively regulated by a Lyn/PI3K module and promoted by SHIP1. J. Immunol. 184, 5809-5818.

Kennah, M., Yau, T. Y., Nodwell, M. Krystal, G., Andersen, R. J., Ong, C. J., and Mui, A. L. (2009). Activation of SHIP via a small molecule agonist kills multiple myeloma cells. Exp. Hematol. 37, 1274-1283.

Kerr, W. G. (2008). A role for SHIP in stem cell biology and transplantation. Curr. Stem Cell Res. Ther. 3, 99-106.

Kerr, W. G. (2011). Inhibitor and activator: dual functions for SHIP in immunity and cancer. Ann. N. Y. Acad. Sci. 1217, 1-17.

Kerr, W. G., Park, M. Y., Maubert, M. and Engelman, R. W. (2011). SHIP deficiency causes Crohn's diseaselike ileitis. Gut 60, 177-188.

Kimura, T., Sakamoto, H., Appella, E., and Siraganian, R. P. (1997). The negative signaling molecule
SH2 domain-containing inositolpolyphosphate 5-phosphatase (SHIP) binds to the tyrosinephosphorylated beta subunit of the high affinity IgE receptor. J. Biol. Chem. 272, 13991-13996.

Knight, Z. A., Gonzalez, B., Feldman, M. E., Zunder, E. R., Goldenberg, D. D., Williams, O., Loewith, R., Stokoe, D., Balla, A., Toth, B., Balla, T., Weiss, W. A., Williams, R. L. and Shokat, K. M. (2006). A pharmacological map of the PI3-K family defines a role for p110alpha in insulin signaling. Cell 125, 733-747.

Kulkarni, S., Sitaru, C., Jakus, Z., Anderson, K. E., Damoulakis, G., Davidson, K., Hirose, M., Juss, J., Oxley, D., Chessa, T. A., Ramadani, F., Guillou, H., Segonds-Pichon, A., Fritsch, A., Jarvis, G. E., Okkenhaug, K., Ludwig, R., Zillikens, D., Mocsai, A., Vanhaesebroeck, B., Stephens, L. R., and Hawkins, P. T. (2011). PI3Kbeta plays a critical role in neutrophil activation by immune complexes. Sci. Signal. 4, ra23.

Kuroda, E., Antignano, F., Ho, V. W., Hughes, M. R., Ruschmann, J., Lam V., Kawakami, T., Kerr, W. G., McNagny, K. M., Sly, L. M., and Krystal, G. (2011). SHIP represses Th2 skewing by inhibiting IL-4 production from basophils. J. Immunol. 186 , 323-332.

Kuroda, E., Ho, V., Ruschmann, J., Antignano, F., Hamilton, M., Rauh, M. J., Antov, A., Flavell, R. A., Sly, L. M., and Krystal, G. (2009). SHIP represses the generation of IL-3-induced M2 macrophages by inhibiting IL-4 production from basophils. J. Immunol. 183, 3652-3660.

Lakhanpal, G. K., Vecchiarelli-Federico, L. M., Li, Y. J., Cui, J. W., Bailey, M. L., Spaner, D. E., Dumont, D. J., Barber, D. L., and Ben-David, Y. (2010). The inositol phosphatase SHIP-1 is negatively regulated by Fli-1 and its loss accelerates leukemogenesis. Blood 116, 428-436.

Lannutti, B. J., Meadows, S. A., Herman, S. E., Kashishian, A., Steiner, B., Johnson, A. J., Byrd, J. C., Tyner, J. W., Loriaux, M. M., Deininger, M., Druker, B. J., Puri, K. D., Ulrich, R. G., and Giese, N. A. (2011). CAL-101, a p110delta selective phosphatidylinositol-3-kinase inhibitor for the treatment of B-cell malignancies, inhibits PI3K signaling and cellular viability. Blood 117, 591-594.

Le Bras, S., Moon, C., Foucault, I., Breittmayer, J. P., and Deckert, M. (2007). Abl-SH3 binding protein 2, 
3BP2, interacts with CIN85 and HIP-55. FEBS Lett. 581, 967-974.

Lee, D. W., Futami, M., Carroll, M., Feng, Y., Wang, Z., Fernandez, M., Whichard, Z., Chen, Y., Kornblau, S., Shpall, E. J., BuesoRamos, C. E., Corey, S. J. (2012). Loss of SHIP-1 protein expression in high-risk myelodysplastic syndromes is associated with miR-210 and miR-155. Oncogene. doi:10.1038/onc.2011.579

Lemmon, M. A., and Ferguson, K. M. (2000). Signal-dependent membrane targeting by pleckstrin homology (PH) domains. Biochem. J. 350(Pt 1), 1-18.

Lesourne, R., Fridman, W. H., and Daeron, M. (2005). Dynamic interactions of $\mathrm{FC}$ gamma receptor IIB with filamin-bound SHIP1 amplify filamentous actin-dependent negative regulation of Fc epsilon receptor I signaling. J. Immunol. 174, 1365-1373.

Li, Y., Wang, L. X., Yang, G., Hao, F., Urba, W. J., and Hu, H. M. (2008). Efficient cross-presentation depends on autophagy in tumor cells. Cancer Res. 68, 6889-6895.

Liu, Q., Sasaki, T., Kozieradzki, I., Wakeham, A., Itie, A., Dumont, D. J., and Penninger, J. M. (1999). SHIP is a negative regulator of growth factor receptor-mediated $\mathrm{PKB} /$ Akt activation and myeloid cell survival. Genes Dev. 13, 786-791.

Locke, N. R., Patterson, S. J., Hamilton, M. J., Sly, L. M., Krystal, G., and Levings, M. K. (2009). SHIP regulates the reciprocal development of $\mathrm{T}$ regulatory and Th17 cells. J. Immunol. 183, 975-983.

Luo, J. M., Liu, Z. L., Hao, H. L., Wang, F. X., Dong, Z. R., and Ohno, R. (2004). Mutation analysis of SHIP gene in acute leukemia. Zhongguo Shi Yan Xue Ye Xue Za Zhi 12, 420-426.

Luo, J. M., Yoshida, H., Komura, S., Ohishi, N., Pan, L., Shigeno, K., Hanamura, I., Miura, K., Iida, S., Ueda, R., Naoe, T., Akao, Y., Ohno, R., and Ohnishi, K. (2003). Possible dominant-negative mutation of the SHIP gene in acute myeloid leukemia. Leukemia 17, 1-8.

Manning, B. D., and Cantley, L. C. (2007). AKT/PKB signaling: navigating downstream. Cell 129, 1261-1274.

Marone, R., Cmiljanovic, V., Giese, B., and Wymann, M. P. (2008). Targeting phosphoinositide 3-kinase: moving towards therapy. Biochim. Biophys. Acta 1784, 159-185.

Martino, R., Caballero, M. D., Canals, C., Simon, J. A., Solano, C., UrbanoIspizua, A., Bargay, J., Rayon,
C., Leon, A., Sarra, J., Odriozola, J., Conde, J. G., Sierra, J., San Miguel, J., ALLOPBSCT Subcommittee of the Spanish Group for Haematopoietic Transplantation (GETH) and Group GELTAMO. (2001). Allogeneic peripheral blood stem cell transplantation with reduced-intensity conditioning: results of a prospective multicentre study. Br. J. Haematol. 115, 653-659.

McLarren, K. W., Cole, A. E., Weisser, S. B., Voglmaier, N. S., Conlin, V. S., Jacobson, K., Popescu, O., Boucher, J. L., and Sly, L. M. (2011) SHIP-deficient mice develop spontaneous intestinal inflammation and arginase-dependent fibrosis. Am. J. Pathol. 179, 180-188.

Meadows, S. A., Vega, F., Kashishian, A., Johnson, D., Diehl, V., Miller, L. L. Younes, A., and Lannutti, B. J. (2012). PI3Kdelta inhibitor, GS-1101 (CAL101), attenuates pathway signaling, induces apoptosis, and overcomes signals from the microenvironment in cellular models of Hodgkin lymphoma. Blood 119, 1897-1900.

Mehta, P., Wavreille, A. S., Justiniano, S. E., Marsh, R. L., Yu, J., Burry, R. W., Jarjoura, D., Eubank, T., Caligiuri, M. A., Butchar, J. P., and Tridandapani, S. (2011). LyGDI, a novel SHIPinteracting protein, is a negative regulator of FcgammaR-mediated phagocytosis. PLoS ONE 6, e21175. doi:10.1371/journal.pone.0021175

Mertins, P., Eberl, H. C., Renkawitz, J., Olsen, J. V., Tremblay, M. L., Mann, M., Ullrich, A., and Daub, H. (2008). Investigation of proteintyrosine phosphatase 1B function by quantitative proteomics. Mol. Cell Proteomics 7, 1763-1777.

Miller, S., Tavshanjian, B., Oleksy, A., Perisic, O., Houseman, B. T., Shokat, K. M., and Williams, R. L. (2010). Shaping development of autophagy inhibitors with the structure of the lipid kinase Vps34. Science 327, 1638-1642.

Mills, S. J., Persson, C., Cozier, G., Thomas, M. P., Tresaugues, L., Erneux, C., Riley, A. M., Nordlund, P., and Potter, B. V. (2012). A synthetic polyphosphoinositide headgroup surrogate in complex with SHIP2 provides a rationale for drug discovery. ACS Chem. Biol. 7, 822-828.

Ming-Lum, A., Shojania, S., So, E., McCarrell, E., Shaw, E., Vu, D., Wang, I., McIntosh, L. P., and Mui, A. L. (2012). A pleckstrin homologyrelated domain in SHIP1 mediates membrane localization during
Fcgamma receptor-induced phagocytosis. FASEB J. doi:10.1096/fj.11201475

Mondal, S., Subramanian, K. K. Sakai, J., Bajrami, B., and Luo, H. R. (2012). Phosphoinositide lipid phosphatase SHIP1 and PTEN coordinate to regulate cell migration and adhesion. Mol. Biol. Cell 23, 1219-1230.

Moon, J. B., Kim, J. H., Kim, K., Youn, B. U., Ko, A., Lee, S. Y., and Kim, N. (2011). Akt induces osteoclast differentiation through regulating the GSK3beta/NFATc1 signaling cascade. J. Immunol. 88 163-169.

Mukherjee, O., Weingarten, L., Padberg, I., Pracht, C., Sinha, R., Hochdorfer, T., Kuppig, S., Backofen, R., Reth, M., and Huber, M. (2012). The SH2-domain of SHIP1 interacts with the SHIP1 C-terminus: Impact on SHIP1/Ig-alpha interaction. Biochim. Biophys. Acta 1823 206-214.

Nakamura, K., Malykhin, A., and Coggeshall, K. M. (2002). The Src homology 2 domain-containing inositol 5-phosphatase negatively regulates Fcgamma receptormediated phagocytosis through immunoreceptor tyrosine-based activation motif-bearing phagocytic receptors. Blood 100, 3374-3382.

Nedjic, J., Aichinger, M., Emmerich, J., Mizushima, N., and Klein, L. (2008). Autophagy in thymic epithelium shapes the T-cell repertoire and is essential for tolerance. Nature 455 396-400.

Nguyen, N. Y., Maxwell, M. J., Ooms, L. M., Davies, E. M., Hilton, A. A., Collinge, J. E., Hilton, D. J., Kile, B. T., Mitchell, C. A., Hibbs, M. L., Jane, S. M., and Curtis, D. J. (2011). An ENU-induced mouse mutant of SHIP1 reveals a critical role of the stem cell isoform for suppression of macrophage activation. Blood 117 5362-5371.

Nishio, M., Watanabe, K., Sasaki, J., Taya, C., Takasuga, S., Iizuka, R., Balla, T., Yamazaki, M., Watanabe, H., Itoh, R. Kuroda, S., Horie, Y., Förster, I., Mak, T. W., Yonekawa, H., Penninger, J. M., Kanaho, Y., Suzuki, A., and Sasaki, T. (2007). Control of cell polarity and motility by the PtdIns $(3,4,5) \mathrm{P} 3$ phosphatase SHIP1. Nat. Cell Biol.9, 36-44.

Norman, P. (2011). Selective PI3Kdelta inhibitors, a review of the patent literature. Expert Opin. Ther. Pat. 21, 1773-1790.

Okada, H., Bolland, S., Hashimoto, A., Kurosaki, M., Kabuyama, Y., Iino, M., Ravetch, J. V., and Kurosaki, T.
(1998). Role of the inositol phosphatase SHIP in B cell receptorinduced $\mathrm{Ca}^{2+}$ oscillatory response. J. Immunol. 161, 5129-5132.

O’Neill, S. K., Getahun, A., Gauld, S. B., Merrell, K. T., Tamir, I., Smith, M. J., Dal Porto, J. M., Li, Q. Z., and Cambier, J. C. (2011). Monophosphorylation of CD79a and CD79b ITAM motifs initiates a SHIP1 phosphatase-mediated inhibitory signaling cascade required for B cell anergy. Immunity 35, 746-756.

Ong, C. J., Ming-Lum, A., Nodwell, M., Ghanipour, A., Yang, L., Williams, D. E., Kim, J., Demirjian, L., Qasimi, P., Ruschmann, J., Cao, L. P., Ma, K., Chung, S. W., Duronio, V., Andersen, R. J., Krystal, G., and Mui, A. L. (2007). Small-molecule agonists of SHIP1 inhibit the phosphoinositide 3-kinase pathway in hematopoietic cells. Blood 110, 1942-1949.

Onnockx, S., de Schutter, J., Blockmans, M., Xie, J., Jacobs, C., Vanderwinden, J. M., Erneux, C., and Pirson, I. (2008). The association between the SH2-containing inositol polyphosphate 5-phosphatase 2 (SHIP2) and the adaptor protein APS has an impact on biochemical properties of both partners. J. Cell. Physiol. 214, 260-272.

Ono, M., Bolland, S., Tempst, P., and Ravetch, J. V. (1996). Role of the inositol phosphatase SHIP in negative regulation of the immune system by the receptor $\mathrm{Fc}$ (gamma)RIIB Nature 383, 263-266.

Ooms, L. M., Horan, K. A., Rahman, P., Seaton, G., Gurung, R., Kethesparan, D. S., and Mitchell, C. A. (2009). The role of the inositol polyphosphate 5-phosphatases in cellular function and human disease. Biochem. J. 419, 29-49.

Osborne, M. A., Zenner, G., Lubinus, M., Zhang, X., Songyang, Z., Cantley, L. C., Majerus, P., Burn, P., and Kochan, J. P. (1996). The inositol $5^{\prime}$-phosphatase SHIP binds to immunoreceptor signaling motifs and responds to high affinity $\operatorname{IgE}$ receptor aggregation. J. Biol. Chem. 271, 29271-29278.

Paternotte, N., Zhang, J., Vandenbroere, I., Backers, K., Blero, D., Kioka, N. Vanderwinden, J. M., Pirson, I., and Erneux, C. (2005). SHIP2 interaction with the cytoskeletal protein Vinexin. FEBS J. 272, 6052-6066.

Peng, Q., Malhotra, S., Torchia, J. A., Kerr, W. G., Coggeshall, K. M., and Humphrey, M. B. (2010). TREM2and DAP12-dependent activation of PI3K requires DAP10 and is inhibited by SHIP1. Sci. Signal. 3, ra38. 
Pilon-Thomas, S., Nelson, N., Vohra, N., Jerald, M., Pendleton, L., Szekeres, K., and Ghansah, T. (2011). Murine pancreatic adenocarcinoma dampens SHIP-1 expression and alters MDSC homeostasis and function. PLoS ONE 6, e27729. doi:10.1371/journal.pone.0027729

Poe, J. C., Fujimoto, M., Jansen, P. J., Miller, A. S., and Tedder, T. F. (2000). CD22 forms a quaternary complex with SHIP, Grb2, and Shc. A pathway for regulation of B lymphocyte antigen receptor-induced calcium flux. J. Biol. Chem. 275, 17420-17427.

Prasad, N., Topping, R. S., and Decker, S. J. (2001). SH2-containing inositol 5'-phosphatase SHIP2 associates with the p130(Cas) adapter protein and regulates cellular adhesion and spreading. Mol. Cell. Biol. 21, 1416-1428.

Qiao, H., Andrade, M. V., Lisboa, F. A., Morgan, K., and Beaven, M. A. (2006). FcepsilonR1 and Toll-like receptors mediate synergistic signals to markedly augment production of inflammatory cytokines in murine mast cells. Blood 107, 610-618.

Raaijmakers, J. H., Deneubourg, L., Rehmann, H., de Koning, J., Zhang, Z., Krugmann, S., Erneux, C., and Bos, J. L. (2007). The PI3K effector Arap3 interacts with the PI $(3,4,5) \mathrm{P} 3$ phosphatase SHIP2 in a SAM domain-dependent manner. Cell. Signal. 19, 1249-1257.

Randis, T. M., Puri, K. D., Zhou, H., and Diacovo, T. G. (2008). Role of PI3Kdelta and PI3Kgamma in inflammatory arthritis and tissue localization of neutrophils. Eur. J. Immunol. 38, 1215-1224.

Rauh, M. J., Ho, V., Pereira, C., Sham, A., Sly, L. M., Lam, V., Huxham, L., Minchinton, A. I., Mui, A., and Krystal, G. (2005). SHIP represses the generation of alternatively activated macrophages. Immunity 23, 361-374.

Rommel, C., Camps, M., and Ji, H. (2007). PI3K delta and PI3K gamma: partners in crime in inflammation in rheumatoid arthritis and beyond? Nat. Rev. Immunol. 7, 191-201.

Ruckle, T., Schwarz, M. K., and Rommel, C. (2006). PI3Kgamma inhibition: towards an "aspirin of the 21st century?” Nat. Rev. Drug Discov. 5, 903-918.

Ruschmann, J., Antignano, F., Lam, V., Snyder, K., Kim, C., Essak, M., Zhang, A., Lin, A. H., Mali, R. S., Kapur, R., and Krystal, G. (2012). The role of SHIP in the development and activation of mouse mucosal and connective tissue mast cells. J. Immunol. 188, 3839-3850.
Ruschmann, J., Ho, V., Antignano, F., Kuroda, E., Lam, V., Ibaraki, M., Snyder, K., Kim, C., Flavell, R. A., Kawakami, T., Sly, L., Turhan, A. G., and Krystal, G. (2010). Tyrosine phosphorylation of SHIP promotes its proteasomal degradation. Exp. Hematol.38, 392-402, 402 e391. Sadhu, C., Masinovsky, B., Dick, K., Sowell, C. G., and Staunton, D. E. (2003). Essential role of phosphoinositide 3-kinase delta in neutrophil directional movement. J. Immunol. 170, 2647-2654.

Saudemont, A., Garcon, F., Yadi, H., Roche-Molina, M., Kim, N., Segonds-Pichon, A., MartinFontecha, A., Okkenhaug, K., and Colucci, F. (2009). pl10gamma and p110delta isoforms of phosphoinositide 3-kinase differentially regulate natural killer cell migration in health and disease. Proc. Natl. Acad. Sci. U.S.A. 106, 5795-5800.

Shenker, B. J., Dlakic, M., Walker, L. P., Besack, D., Jaffe, E., LaBelle, E., and Boesze-Battaglia, K. (2007). A novel mode of action for a microbialderived immunotoxin: the cytolethal distending toxin subunit $\mathrm{B}$ exhibits phosphatidylinositol 3,4,5triphosphate phosphatase activity. J. Immunol. 178, 5099-5108.

Shuttleworth, S. J., Silva, F. A., Cecil, A. R., Tomassi, C. D., Hill, T. J., Raynaud, F. I., Clarke, P. A., and Workman, P. (2011). Progress in the preclinical discovery and clinical development of class I and dual class I/IV phosphoinositide 3-kinase (PI3K) inhibitors. Curr. Med. Chem. 18, 2686-2714.

Simonsen, A., and Tooze, S. A. (2009). Coordination of membrane events during autophagy by multiple class III PI3-kinase complexes. J. Cell Biol. 186, 773-782.

Sly, L. M., Rauh, M. J., Kalesnikoff, J., Song, C. H., and Krystal, G. (2004). LPS-induced upregulation of SHIP is essential for endotoxin tolerance. Immunity 21, 227-239.

So, L., and Fruman, D. A. (2012). PI3K signalling in B- and T-lymphocytes: new developments and therapeutic advances. Biochem. J. 442, 465-481.

Song, M., Kim, M. J., Ha, S., Park, J. B., Ryu, S. H., and Suh, P. G. (2005). Inositol 5'-phosphatase, SHIP1 interacts with phospholipase C-gammal and modulates EGFinduced PLC activity. Exp. Mol. Med. 37, 161-168.

Song, M. S., Salmena, L., and Pandolfi, P. P. (2012). The functions and regulation of the PTEN tumour suppressor. Nat. Rev. Mol. Cell Biol. 13, 283-296.
Sorisky, A., King, W. G., and Rittenhouse, S. E. (1992). Accumulation of PtdIns(3,4)P2 and PtdIns(3,4,5)P3 in thrombin-stimulated platelets. Different sensitivities to $\mathrm{Ca}^{2+}$ or functional integrin. Biochem. J. 286(Pt 2), 581-584.

Srivastava, S., Di, L., Zhdanova, O., Li, Z., Vardhana, S., Wan, Q., Yan, Y., Varma, R., Backer, J., Wulff, H., Dustin, M. L., and Skolnik, E. Y. (2009). The class II phosphatidylinositol 3 kinase C2beta is required for the activation of the $\mathrm{K}^{+}$channel KCa3.1 and CD4 T-cells. Mol. Biol. Cell 20, 3783-3791.

Suwa, A., Kurama, T., and Shimokawa, T. (2010). SHIP2 and its involvement in various diseases. Expert Opin. Ther. Targets 14, 727-737.

Suwa, A., Yamamoto, T., Sawada, A., Minoura, K., Hosogai, N., Tahara, A., Kurama, T., Shimokawa, T., and Aramori, I. (2009). Discovery and functional characterization of a novel small molecule inhibitor of the intracellular phosphatase, SHIP2. Br. J. Pharmacol. 158, 879-887.

Tamir, I., Stolpa, J. C., Helgason, C. D., Nakamura, K., Bruhns, P., Daeron, M., and Cambier, J. C. (2000). The RasGAP-binding protein p62dok is a mediator of inhibitory FcgammaRIIB signals in B cells. Immunity 12, 347-358.

Tarasenko, T., Kole, H. K., Chi, A. W., Mentink-Kane, M. M., Wynn, T. A., and Bolland, S. (2007). T cell-specific deletion of the inositol phosphatase SHIP reveals its role in regulating Th1/Th2 and cytotoxic responses. Proc. Natl. Acad. Sci. U.S.A. 104, 11382-11387.

Tessmer, M. S., Fugere, C., Stevenaert, F., Naidenko, O. V., Chong, H. J., Leclercq, G., and Brossay, L. (2007). KLRG1 binds cadherins and preferentially associates with SHIP-1. Int. Immunol. 19, 391-400.

Tiwari, S., Choi, H. P., Matsuzawa, T., Pypaert, M., and MacMicking, J. D. (2009). Targeting of the GTPase Irgml to the phagosomal membrane via PtdIns $(3,4) \mathrm{P}(2)$ and PtdIns $(3,4,5) \mathrm{P}(3)$ promotes immunity to mycobacteria. Nat. Immunol. 10, 907-917.

Tomlinson, M. G., Heath, V. L., Turck, C. W., Watson, S. P., and Weiss, A. (2004a). SHIP family inositol phosphatases interact with and negatively regulate the Tec tyrosine kinase. J. Biol. Chem. 279, 55089-55096.

Tomlinson, M. G., Kane, L. P., Su, J., Kadlecek, T. A., Mollenauer, M. N., and Weiss, A. (2004b). Expression and function of Tec, Itk, and Btk in lymphocytes: evidence for a unique role for Tec. Mol. Cell. Biol. 24, 2455-2466.

Vandenbroere, I., Paternotte, N., Dumont, J. E., Erneux, C., and Pirson, I. (2003). The c-Cbl-associated protein and $\mathrm{c}-\mathrm{Cbl}$ are two new partners of the SH2-containing inositol polyphosphate 5-phosphatase SHIP2. Biochem. Biophys. Res. Commun. 300, 494-500.

Vandeput, F., Combettes, L., Mills, S. J., Backers, K., Wohlkonig, A., Parys, J. B., de Smedt, H., Missiaen, L., Dupont, G., Potter, B. V., and Erneux, C. (2007). Biphenyl 2,3',4,5',6pentakisphosphate, a novel inositol polyphosphate surrogate, modulates $\mathrm{Ca}^{2+}$ responses in rat hepatocytes. FASEB J. 21, 1481-1491.

Vanderwinden, J. M., Wang, D., Paternotte, N., Mignon, S., Isozaki, K., and Erneux, C. (2006). Differences in signaling pathways and expression level of the phosphoinositide phosphatase SHIP1 between two oncogenic mutants of the receptor tyrosine kinase KIT. Cell. Signal. 18, 661-669.

Vanhaesebroeck, B., Ali, K., Bilancio, A., Geering, B., and Foukas, L. C. (2005). Signalling by PI3K isoforms: insights from gene-targeted mice. Trends Biochem. Sci. 30, 194-204.

Vanhaesebroeck, B., GuillermetGuibert, J., Graupera, M., and Bilanges, B. (2010). The emerging mechanisms of isoform-specific PI3K signalling. Nat. Rev. Mol. Cell Biol. 11, 329-341.

Vanhaesebroeck, B., Stephens, L., and Hawkins, P. (2012). PI3K signalling: the path to discovery and understanding. Nat. Rev. Mol. Cell Biol. 13, 195-203.

Vieira, O. V., Botelho, R. J., Rameh, L., Brachmann, S. M., Matsuo, T., Davidson, H. W., Schreiber, A., Backer, J. M., Cantley, L. C., and Grinstein, S. (2001). Distinct roles of class I and class III phosphatidylinositol 3-kinases in phagosome formation and maturation. J. Cell Biol. 155, 19-25.

Wahle, J. A., Paraiso, K. H., Kendig, R. D., Lawrence, H. R., Chen, L., Wu, J., and Kerr, W. G. (2007). Inappropriate recruitment and activity by the Src homology region 2 domaincontaining phosphatase 1 (SHP1) is responsible for receptor dominance in the SHIP-deficient NK cell. J. Immunol. 179, 8009-8015.

Wain, C. M., Westwick, J., and Ward, S. G. (2005). Heterologous regulation of chemokine receptor signaling by the lipid phosphatase SHIP 
in lymphocytes. Cell. Signal. 17, 1194-1202.

Walker, E. H., Pacold, M. E., Perisic, O., Stephens, L., Hawkins, P. T., Wymann, M. P., and Williams, R. L. (2000). Structural determinants of phosphoinositide 3-kinase inhibition by wortmannin, LY294002, quercetin, myricetin, and staurosporine. Mol. Cell 6, 909-919.

Walsh, C. M., and Edinger, A. L. (2010). The complex interplay between autophagy, apoptosis, and necrotic signals promotes $\mathrm{T}$-cell homeostasis. Immunol. Rev. 236, 95-109.

Wang, J. W., Howson, J. M., Ghansah, T., Desponts, C., Ninos, J. M., May, S. L., Nguyen, K. H., Toyama-Sorimachi, N., and Kerr, W. G. (2002). Influence of SHIP on the NK repertoire and allogeneic bone marrow transplantation. Science 295, 2094-2097.

Ward, S. G., and Marelli-Berg, F. M. (2009). Mechanisms of chemokine and antigen-dependent T-lymphocyte navigation. Biochem. J. 418, 13-27.

Waterman, P. M., Marschner, S., Brandl, E., and Cambier, J. C. (2012). The inositol 5-phosphatase SHIP1 and adaptors Dok-1 and 2 play central roles in CD4-mediated inhibitory signaling. Immunol. Lett. $143,122-130$.

Weaver, C. T., and Murphy, K. M. (2007). The central role of the Th17 lineage in regulating the inflammatory/autoimmune axis. Semin. Immunol. 19, 351-352.

Workman, P., Clarke, P. A., Raynaud, F. I., and van Montfort, R. L. (2010). Drugging the PI3 kinome: from chemical tools to drugs in the clinic. Cancer Res. 70, 2146-2157.

Wullschleger, S., Wasserman, D. H., Gray, A., Sakamoto, K., and Alessi, D. R. (2011). Role of TAPP1 and TAPP2 adaptor binding to PtdIns(3,4)P2 in regulating insulin sensitivity defined by knock-in analysis. Biochem. J. 434, 265-274.

Xie, J., Onnockx, S., Vandenbroere, I., Degraef, C., Erneux, C., and Pirson, I. (2008a). The docking properties of SHIP2 influence both JIP1 tyrosine phosphorylation and JNK activity. Cell. Signal. 20, 1432-1441.

Xie, J., Vandenbroere, I., and Pirson, I. (2008b). SHIP2 associates with intersectin and recruits it to the plasma membrane in response to EGF. FEBS Lett. 582, 3011-3017.
Yang, L., Williams, D. E., Mui, A. Ong, C., Krystal, G., van Soest, R., and Andersen, R. J. (2005). Synthesis of pelorol and analogues: activators of the inositol 5-phosphatase SHIP. Org. Lett. 7, 1073-1076.

Zhang, J., Ravichandran, K. S., and Garrison, J. C. (2010). A key role for the phosphorylation of Ser 440 by the cyclic AMP-dependent protein kinase in regulating the activity of the Src homology 2 domain-containing inositol $5^{\prime}$ phosphatase (SHIP1). J. Biol. Chem. 285, 34839-34849.

Zhang, T. T., Li, H., Cheung, S. M., Costantini, J. L., Hou, S., AlAlwan, M., and Marshall, A. J. (2009). Phosphoinositide 3-kinaseregulated adapters in lymphocyte activation. Immunol. Rev. 232, 255-272.

Zwaenepoel, K., Goris, J., Erneux, C., Parker, P. J., and Janssens, V. (2010). Protein phosphatase 2A PR130/B"alphal subunit binds to the $\mathrm{SH} 2$ domain-containing inositol polyphosphate 5-phosphatase 2 and prevents epidermal growth factor (EGF)-induced EGF receptor degradation sustaining
EGF-mediated signaling. FASEB $J$. $24,538-547$.

Conflict of Interest Statement: The authors declare that the research was conducted in the absence of any commercial or financial relationships that could be construed as a potential conflict of interest.

Received: 26 April 2012; paper pending published: 11 June 2012; accepted: 12 July 2012; published online: 02 August 2012.

Citation: Blunt MD and Ward SG (2012) Pharmacological targeting of phosphoinositide lipid kinases and phosphatases in the immune system: suc cess, disappointment, and new opportunities. Front. Immun. 3:226. doi: 10.3389/fimmu.2012.00226

This article was submitted to Frontiers in $T$ Cell Biology, a specialty of Frontiers in Immunology.

Copyright () 2012 Blunt and Ward. This is an open-access article distributed under the terms of the Creative Commons Attribution License, which permits use, distribution and reproduction in other forums, provided the original authors and source are credited and subject to any copyright notices concerning any third-party graphics etc. 